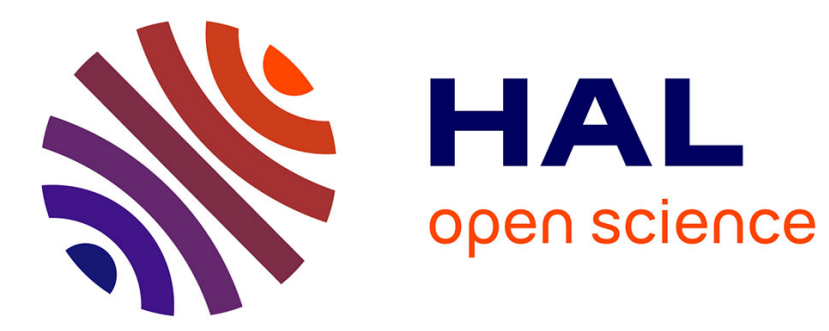

\title{
An Overview of the Circulation of Glass in Antiquity
}

Danièle Foy

\section{To cite this version:}

Danièle Foy. An Overview of the Circulation of Glass in Antiquity. Andrew Wilson; Alan Bowman. Trade, Commerce and the State in the Roman World, Oxford University Press, pp.265-300, 2018, Oxford Studies on the Roman Economy, 978-0-19-879066-2. halshs-03524997

\section{HAL Id: halshs-03524997 https://shs.hal.science/halshs-03524997}

Submitted on 13 Jan 2022

HAL is a multi-disciplinary open access archive for the deposit and dissemination of scientific research documents, whether they are published or not. The documents may come from teaching and research institutions in France or abroad, or from public or private research centers.
L'archive ouverte pluridisciplinaire HAL, est destinée au dépôt et à la diffusion de documents scientifiques de niveau recherche, publiés ou non, émanant des établissements d'enseignement et de recherche français ou étrangers, des laboratoires publics ou privés. 
This innovative monograph series reflects a vigorous revival of interest in the ancient economy, focusing on the Mediterranean world under Roman rule (c.100 $\mathrm{BC}$ to $\mathrm{AD} 350$ ). Carefully quantified archaeological and documentary data will be integrated to help ancient historians, economic historians, and comparative element and thus be of interest to historians of other periods and places.

\section{Trade, Commerce, and the State in the Roman World}

Edited by

ANDREW WILSON AND

ALAN BOWMAN
OXFORD

UNIVERSITY PRESS 


\section{An Overview of the Circulation of Glass in Antiquity}

Danièle Foy

A discussion of commerce in glass in the ancient Mediterranean must engage with very different categories of objects. The variety of glass products that were traded is explained principally by the way in which glass was produced.

\section{THE OPERATIONAL SEQUENCE}

OF GLASS PRODUCTION

A new picture of the process of glass production in antiquity has emerged from the combination of archaeometric techniques for defining the composition of glass, archaeological discoveries chiefly of glass workshops and shipwrecks, and a re-examination of literary sources. Unlike pottery, which could be made with ingredients of different qualities but which were available almost everywhere, ancient glass required specific raw materials for its manufacture, which implies a system of staged or disintegrated production comparable to the metallurgical industry. At the start of the process, the primary workshops, mainly established in the eastern Mediterranean, produced raw glass from local sands and from natron obtained either locally or imported. The secondary centres, spread throughout the whole Empire, transformed the imported raw glass into manufactured products.

For a long time, the homogeneity of the composition of ancient glass has been remarked upon, and is today explained by the use of raw materials from the same geological deposits. The pioneering work of Robert Brill on the workshop of Jalamé in Israel has demonstrated that the glass produced in this secondary workshop, dated to the second half of the fourth century AD, was made from two ingredients, of which one, the sand, contained two essential 
constituents: silica and lime, naturally present in the shelly sand extracted from the estuary of the River Belus, to the south of Acre (Akko). ${ }^{1}$ Egyptian natron served as the flux, the third essential constituent.

The characteristics of the sands close to which the primary workshops were established provide the genetic map, as it were, of different types of glass. Analyses of the composition of a glass object reveal the geographical area in which the primary workshops were located. These technical data (the use of only two ingredients) and the geographical origin of one of the most heavily exploited sand sources were already contained in Pliny the Elder's account describing the discovery of glass (NH 36.65): the geographical zone mentioned, the use of local sands, and the importation of natron, a carbonate of soda that lowered the fusing point of the sand, are correct and precise pieces of information.

Numerous analyses of glass composition prove in effect that the sands of the Belus river, and more generally those of the Palestinian coast, were extensively used for the manufacture of glass from the Hellenistic period until the end of antiquity. The majority of the glass of the High Empire found in the West seems to have been made with this material. Outside this region, archaeometry shows that other sand deposits were exploited by the glass industry; the locations of some are more or less well established, but others remain unidentified. It remains the case, however, that the areas of production of raw glass in antiquity were limited in number, and that numerous secondary workshops, sometimes very distant from each other, could use glass of the same origin A single secondary workshop might also be supplied from multiple sources. In consequence, the chemical analyses cannot individuate the production of a secondary workshop, but they identify a geographical zone of production for the raw material. In reality, things are not as simple as that, because the mixture of different raw glass types, and especially the introduction of recycled broken glass, confuses the issue; it seems, moreover, that certain primary workshops could also produce glass of different qualities. ${ }^{2}$

Away from the Syro-Palestinian coast, the texts, archaeometry, and excavations of primary workshops enable us to locate other production areas, in particular in Egypt, to the south of Alexandria, ${ }^{3}$ and perhaps in Africa. ${ }^{4}$ But this glass, as we shall see in this chapter, was not always intended for the western market. Finally, there are compositional groups whose origin or origins remain unknown.

In the primary workshops, the production of raw glass was carried out in large rectangular furnaces. The fusion of sand and natron resulted in a slab of glass, which was hacked into shapeless chunks. Loaded onto ships or caravans

$$
\begin{aligned}
& { }^{1} \text { Brill (1988). }{ }^{2} \text { Nenna et al. (2005: fig. 4). } \\
& { }^{3} \text { Nenna, Picon, and Vichy (2000). } \\
& { }_{4}^{4} \text { Foy (2003a). }
\end{aligned}
$$

of animals, these blocks of glass were exported to secondary workshops to be remelted and transformed into manufactured products.

The excavations of an Egyptian workshop of the High Empire, located in the Wadi Natrun, ${ }^{5}$ and of the workshop of Bet Eli'ezer in Israel, dated at the very start of the Islamic period, ${ }^{6}$ have revealed the productive capacity of these establishments: the workshop at Wadi Natrun could produce over 15 tonne in a single furnace, and the one at Bet Eli'ezer up to 7 tonnes. These workshops were probably seasonally operated, but their production capacity remain phenomenal if one considers that perfume bottles weigh between 10 and $50 \mathrm{~g}$ and that the largest glass items rarely exceed $1.5 \mathrm{~kg}$. Produced probably at a high profit, this raw glass was carefully recuperated in the primary workshops for sale. On site, in fact, there remained almost no shards of glass that had been missed.

\section{TRADE IN GLASS}

\section{The raw materials: Raw glass and glass for recycling}

We are poorly informed about the circulation of sand. ${ }^{7}$ Texts and archaeometry nevertheless allow us to identify the transport of silica-rich sand both for the Palestinian workshops and for the Egyptian workshops. Strabo clearly states that the sand between Tyre and Akko was used for the workshops of Sidon, ${ }^{8}$ and Flavius Josephus mentions the numerous ships that loaded the vitrifiable sand of the Belus estuary. ${ }^{9}$ The identification of different glass compositional groups in the same primary workshops of the Wadi Natrun in Egypt (above) requires us to envisage the transport of sand, over short or long distances.

Only the workshops of the Wadi Natrun were located next to natron sources. The workshops of the Palestinian coast had to import large quantities of natron, of which only the analyses performed on the glass of Jalamé confirm an Egyptian origin. Other provenances are also imaginable, in particular Lydia, renowned for providing the best product, and Macedonia, ${ }^{10}$ which produced it in abundance and quality. ${ }^{11}$ This carbonate, used for numerous purposes, travelled in various forms, mentioned by Pliny the Elder: ${ }^{12}$ in lumps, in powdered form, presumably, 'packed in pots' (Egyptian natron), and as

Nenna (2008a: 61). $\quad{ }^{6}$ Gorin-Rosen (2000: 52-3).

We know, however, that sand could be imported from very far away (Ethiopia, India) for use in cutting marble: Pliny, $\mathrm{NH} 36.9$

${ }_{11}^{8}$ Geography 16.25. ${ }_{9}$ Jewish War 2.188. $\quad{ }^{10}$ Ignatiadou et al. (2005). 
tablets (natron from Lydia). Whatever its origin and appearance, the natron that entered the composition of glass participated in an interprovincial trade. Mixed with Levantine sands, it became raw glass, which was in its turn sent to the secondary workshops of the entire ancient world.

Because it is soluble, natron has left no trace of these movements. There remain, however, numerous indications of the circulation of raw glass in the West, both by sea and by riverine and terrestrial routes (Fig. 9.1). The most significant evidence appears from the Hellenistic period onwards in three wrecks off the south of France. The most eloquent deposit, from the Les Sanguinaires A wreck, off Ajaccio, is estimated at a tonne, a cargo that clearly reveals the astonishing capacity of production, at this period, when the process of blowing glass was not yet known. Workshops in the eastern Mediterranean, or in the Punic world, could be the origin of this glass. ${ }^{13}$

During the High Empire, the Syro-Palestinian workshops, which made a bluish glass, dominated the market for raw glass exported towards the western provinces of the Empire. The evidence directly concerning transport is not sufficiently abundant for us to evaluate the place of glass in the trade in raw materials. Some observations on the development of grave goods, in particular balsamaria, suggest an increase in the arrival of raw glass from the second third of the first century $\mathrm{AD}$, when the use of small tubular flasks in funerary ceremonies became widespread. The blowing of these balsamaria (type 8 in C. Isings's classification ${ }^{14}$ ), always in bluish glass and very common, requires twice as much material as the making of the earlier small flasks in fine and coloured glass (Isings 6) of the Augustan period. The vessels that succeeded them increased even more in density: in the Flavian period, the most common flask is a receptacle with a conical belly (Isings 28 ) whose average weight is $40 \mathrm{~g}$ or four times as much as the Augustan flasks. The development of these objects as well as the 'democratization' of glassware, which became more and more abundant from the middle of the first century $A D$ in domestic and funerary contexts, show clearly that glassmakers had no problems obtaining all the necessary materials.

The principal archaeological attestations of this trade in the first century $\mathrm{AD}$ are the glass blocks found in the secondary workshops of Avenches, ${ }^{15}$ Lyons, ${ }^{16}$ and Pompeii, ${ }^{17}$ as well as in ships (in particular, the wreck from Mjlet in Croatia) ${ }^{18}$ or even in dumps at maritime or river ports (finds from Provence and Languedoc). ${ }^{19}$ Although modest, the fragments from deposits in the river port at Arles show the penetration of this glass from the Mediterranean to secondary workshops located inland.

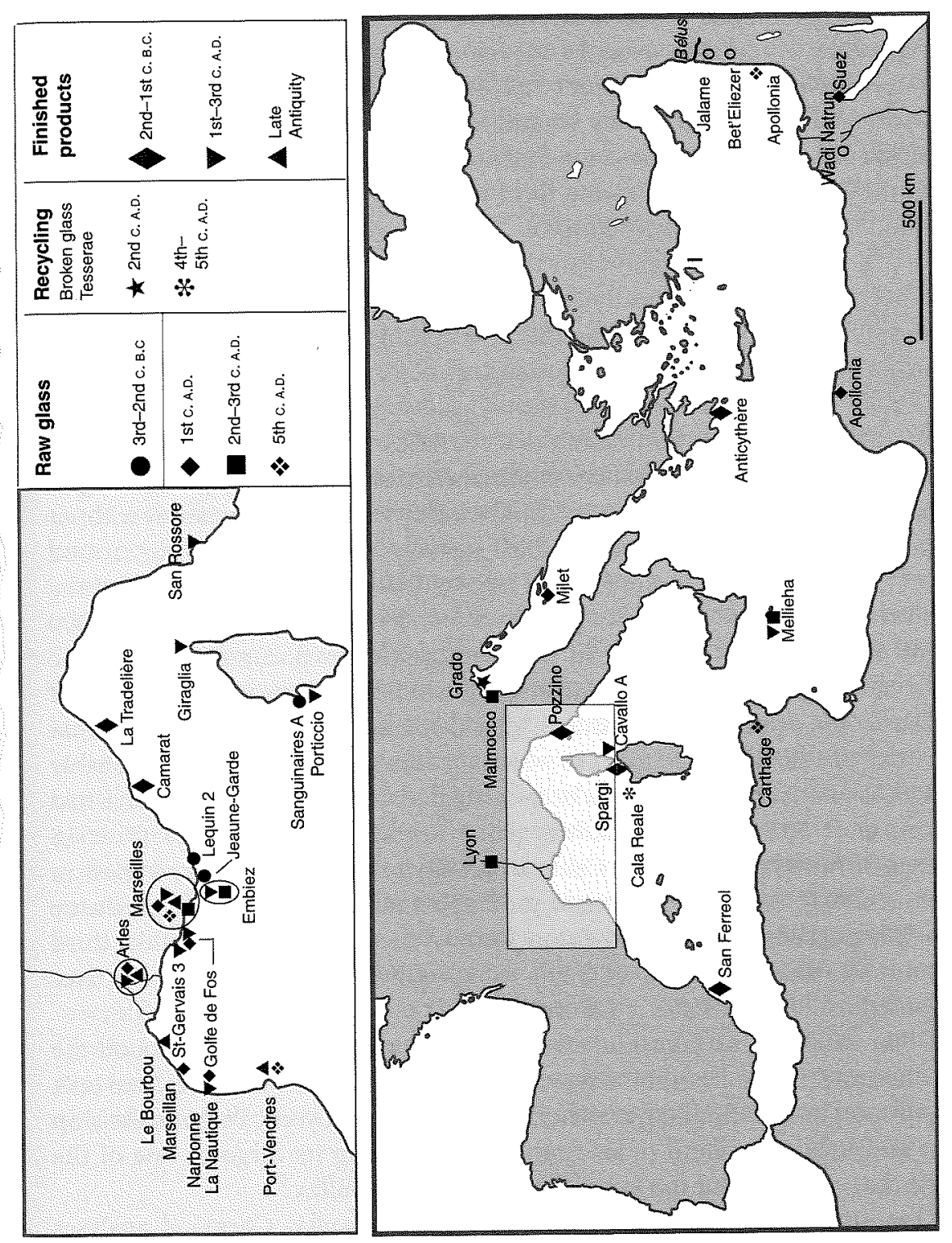

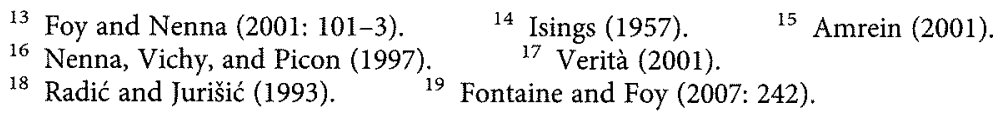


Egypt as a producer of raw glass appears turned towards the Indian Ocean in the imperial period. The particular composition of the sands of Mareoti and Wadi Natrun, where the workshops are located, is not found in western glass, with few exceptions. The Periplus of the Red Sea (Periplus Maris Erythraei), composed towards the middle of the first century $\mathrm{AD}$, mentions the transport of raw glass from the Mediterranean towards the ports of the Red Sea via the Nile. The discovery of two blocks of raw glass in the excavations of the fort of Didymoi illustrates magnificently the route of this merchandise from the Nile to the sea, across the mountains of the Eastern Desert of Egypt. ${ }^{20}$

In the course of the second and third centuries, the taste for colourless glass spread throughout the whole Empire. This fact seems to reflect the emergence of new areas of production, which took a share of the market that until then had been chiefly dominated by the Levantine production centres. Numerous analyses have been performed on this very common material, which was used to make both sumptuous and very mundane objects: the location of the areaor areas-of production of this kind of glass remains hotly debated..$^{21}$ The most striking evidence for trade in this colourless raw material is the Embiez Ouest wreck on the Provençal coast: this ancient ship, whose cargo was largely composed of raw glass, glass vessels, and windows of different types, is without parallel. Sunk at the start of the third century $\mathrm{AD}$, it was carrying around 18 tonnes of raw glass in the form of large chunks, which must represent the equivalent of one or two slabs of glass from the furnace, and at least 2,000 items of glassware, and some 50 windowpanes. ${ }^{22}$ No document tells us the value of raw glass and of glassware at this period, but, if one refers to the Edict of Diocletian, promulgated a century after the wreck of this ship, one sees that the price of colourless raw glass, to which the term Alexandrian glass probably relates, is relatively high. ${ }^{23}$ It has been calculated that this ship would have had to transport 50,000 items of blown glass to equal the value of the 17 or 18 tonnes of raw glass on board. One can see how the transport of raw glass in bulk is clearly less risky and more profitable than carrying fragile glassware carefully packed. That said, we do not know if the colourless glass of the third century AD, which seems banal, had a value equivalent to that which was later accorded to it by the Edict of Diocletian.

Other evidence for the circulation of colourless glass is known around the Mediterranean coastline, in the wreck at the Bourse site in Marseilles, and on a river route, in an unloading area next to the Saone at Lyons. Perhaps the ship that sank near the island of les Embiez was carrying its cargo to one of the ports that commanded the approach to the Rhône valley. ${ }^{24}$

Levantine raw glass was still traded in late antiquity. Chemical analyses show the similarity in composition between western objects and raw glass of

${ }^{20}$ Brun (2003).
${ }^{23}$ Stern (1999: 460-6). the Syro-Palestinian coast ${ }^{25}$ We have no direct evidence, however, from underwater discoveries about the arrival of this raw glass in the western Mediterranean.

Other primary workshops, whose location remains unknown, tried to rival the vast Levantine production, and we have proof of this in the waste of a small workshop established on the outskirts of Arles in the second half of the fourth century $A D .{ }^{26}$ It recycled a colourless glass, very different from that which is found in abundance at the end of the second and in the third century. ${ }^{27}$

But the greatest disruption in the supply of raw glass occurred at the very start of the fifth century with the arrival of a dark greenish-yellow, but shiny, glass, produced in the Egyptian Sinai. ${ }^{28}$ This material, which represents over 80 per cent of the glassware used in Mediterranean France at the period, is also very abundant in Catalonia, Italy, ${ }^{29}$ Africa, and the Black Sea. It was used in the workshops identified at Marseilles, Arles, Tarragona, ${ }^{30}$ Carthage, ${ }^{31}$ Rome, Classe, ${ }^{32}$ and probably also in Sicily at Sofiana. ${ }^{33}$ We do not know any wrecks transporting this material, which is nonetheless present in the port deposits of Port-Vendres and Marseilles. Outside the Mediterranean region, this raw glass is also reported from Toulouse, in Aquitaine, as well as in the north-east of the Iberian peninsula. ${ }^{34}$ For three-quarters of a century it was widely distributed and recycled not only as far afield as the workshops of the Atlantic coast, but probably also in more northerly production centres, because it is found in the composition of numerous pieces of glassware and in windowpanes of northern Gaul. From Egypt, probably again, came raw glass that was used in the workshops of Aquitaine, Languedoc, Provence, ${ }^{35}$ and probably Africa and Italy, which were active in the sixth and seventh centuries, but this material, abundant in the western Mediterranean, was not widely distributed further north. Thus, for two centuries, Egypt captured the bulk of the market in raw glass intended for the workshops of the western Mediterranean.

Broken glass for recycling was probably collected in every town. This practice, well attested in the texts from the end of the first century $\mathrm{AD}$, is hard to demonstrate outside the dumps associated with artisanal quarters. The only evident archaeological example of the circulation of broken glass is the assemblage of fragments found in a barrel from the wreck Julia Felix, near Grado (northern Adriatic), dated to the second century. ${ }^{36}$ This site certainly represents transport over short distances, because the glass items come from the workshops of northern Italy. Unfortunately, however, the evidence is lacking to

\footnotetext{
${ }^{25}$ Freestone, Gorin-Rosen, and Hughes (2000); Foy et al. (2003) 27 Foy, Thirion-Merle, and Vichy (2004: analysis VRR 711).

${ }^{28}$ Foy et al (2003: 48-55). Freestone (2006): Freestone Wolf, and Thirlwall (2005).

29 Mirti, Casoli, and Appolonia (1993). 30 Benet and Subias i Pascual (1989).

31 Freestone (1994). 32 Tontini (2006). 33 Narbone (1997: 291).

${ }^{34}$ Cruz (2009: i. 74-7). $\quad{ }^{35}$ Foy et al. (2003: 55-60). ${ }_{36}$ Giacobelli (1997; 2002).
} 
support the hypothesis of long-distance exchange of recycled glass, such as appears in the Middle Ages.

Other semi-finished materials connected with the manufacture of glass are worth mentioning even if they do not represent an important proportion of the trade. The tesserae or cubes of coloured glass frequently found in late antique secondary glassblowing workshops were used as colourants. One can

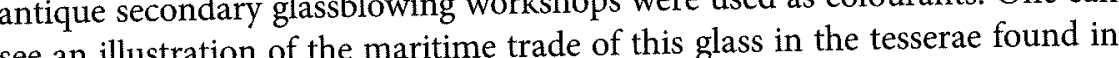
see an illustration of the maritime trade of this glass in the tesserae found in the wreck of the end of the fourth century at Cala Reale, the Asinara 1 in Sardinia, ${ }^{37}$ coming from Baetica. One cannot entirely exclude the idea that these coloured cubes formed part of an emblema or that they might have been used by mosaicists, but the frequent finds of cakes of coloured glass at the sites of mosaic-laying leads one to believe that the semi-finished product of mosaicists circulated in the form of glass disks. One could thus propose the hypothesis that circulated in the for these cubes transported from Baetica (or from Africa?) were used to colour glass, a practice that is reported in the twelfth century, but that already existed at the end of antiquity.

\section{Manufactured glass objects}

The circulation of raw glass does not exclude that of glass objects, but there are The circulation of raw glass does not exclude that of gecause the origin of numerous productions remains unknown for various reasons. First of all, the practice of recycling does not always allow us to discriminate between products entering recycling drom products made on site; the the glassblowing workshop to be recycled from products made on site; the process that means that all the rejects are recycled prevents the formation of workshop dumps. The second difficulty is linked to the fact that very distant works similar forms, often with the same imported workshops apparently produced similar forms, often with the same imported raw glass. This has been observed for the workshops of the middle of the first century AD established at Avenches (Switzerland), Lyons, and Reims, which have a number of products in common. Finally, it is difficult to assess the dynamism of the market on the basis of only very limited evidence: glass, even in the richest contexts, represents only a tiny part of the material culture in use in the Roman world, except in certain necropoleis of the Flavian period.

\section{Glass vessels and windows}

Before the last third of the first century $\mathrm{BC}$, glass vessels were almost nonexistent in the West, and these objects, decorated or plain, must be considered as luxury items. From this period onwards, moulded bowls made on the SyroPalestinian coast began to arrive. The most convincing demonstration of this organized trade is the Provençal wreck of La Tradelière, dated around the 30s or $20 \mathrm{~s} \mathrm{BC}^{38}$ The glass factories of this period are already present, but in limited numbers in Gaul and Britain ${ }^{39}$ in some settlements, but especially in elite tombs and sanctuaries, which were the centres of attraction, so to speak, for this material.

Luxury glassware-mosaic cups from Italian workshops of the beginning of the first century $\mathrm{AD}$, mould-blown glass from workshops in the Levant or Asia Minor, pieces decorated with coloured applique filaments from the Rhineland workshops of the third century, or the engraved glass or gold-leaf glass of the fourth century from Italian workshops-circulated in small numbers, but the distribution range of certain production centres extended a very long distance.

This trade from west to east and from east to west can be exemplified by some types of objects. Thus, on the shores of the Indian Ocean are found moulded and coloured pieces from the Augustan workshops established in Campania or in the region around Rome. Ribbed cups, aryballoi from Italy and the Near East, moulded glass from the workshops of Sidon, mosaiced pearls from Egypt are found in the Arabian Gulf at Ed-Dur, ${ }^{40}$ in the tombs of Mleiha ${ }^{41}$ and in the necropoleis of Bahrain, ${ }^{42}$ but also in southern India at Arikamedu, where Italian terra sigillata and Italian amphorae are reported. The finds from Begram, interpreted as a royal treasure or as the merchandise from a commercial entrepot, comprise 180 glass objects dated from the first to the third centuries AD; they provide the most beautiful illustration of the longdistance trade in luxury and common glasswares. ${ }^{43}$

Goods arriving in the other direction are also traceable. In the middle decades of the first century $\mathrm{AD}$, glass vessels with inscriptions in Greek or even ornamental motifs attributable to the workshop of the glassblower Ennion of Sidon, are present in the Black Sea, the whole of Italy, and the provinces north of the Alps. In northern Italy their abundance is such that it has been supposed that Ennion had a branch workshop there. These vessels also reached the western extremity of the Mediterranean and the most northerly Roman settlements, especially in Great Britain, ${ }^{44}$ as well as Nijmegen and Valkenburg in the Low Countries, ${ }^{45}$ and Tongres in Belgium. ${ }^{46}$

Although luxury Italian glasswares, imported in the Augustan and Tiberian period, have been found mostly in military forts, ${ }^{47}$ others in urban and funerary contexts clearly attest a veritable commerce. The gold-band glasswares (made with gold leaf sandwiched between two layers of plain glass),

${ }^{38}$ Feugère and Leyge (1989). $\quad{ }^{39}$ Price (1996).
${ }^{41}$ Boucharlat (1989).
${ }^{44}$ Nenna (1999).
${ }^{44}$ RIB II.2, 2419.38.
${ }^{47}$ Trenningehouse (1998).
Tremmel (2006).


which are some of the most sumptuous items produced in Italy from the end of the first century $\mathrm{BC}$, are rare but nevertheless widely dispersed, the most westerly pieces being from the south of Portugal and the most northerly in England (Fishbourne) and Cologne. ${ }^{48}$ Coloured and worked glasswares, called cameo glass, were also the object of very long-distance trade, as their distribution maps show. From Italy, they were spread to the west through distribut further to the north in Gallia Belgica and even as far as Norway. To the south, they reached the furthest point of the Iberian peninsula, and, to the east, Iran and Pakistan. ${ }^{50}$

Painting on glass was practised in several glassblowing centres of the second half of the first century $\mathrm{AD}$. These pieces travelled: the large painted glass vessels discovered at Begram (Afghanistan) very probably originated in Egypt. The bowls of type Isings 12, an extremely common form in the middle decades of the first century, could have been made in several places, but northern Italy is almost certain as a production area. Very prized, these glass vessels were distributed to nearly all the western provinces, to the north (principally Switzerland, then Germany, Slovenia, the Low Countries, Great Britain), to Gaul (twelve scattered attestations), but also to Africa and the Black Sea; other finds are attested in Egypt, Palestine, and Asia Minor (Fig. 9.2). ${ }^{51}$ The dynamism of the Italian workshops was maintained throughout antiquity, but it is impossible to assess the part played by imports because, as has already been said, the productions of non-Italian workshops active from the mid first century cannot be distinguished from them.

The apparent uniformity of the ordinary glasswares of the first and second centuries $\mathrm{AD}$ - that is to say, the undecorated wares blown in bluish or greenish rather than colourless glass-does not indicate the total absence of regional variations. Specific forms have been distinguished in several geographic zones. These characteristic pieces seem to be reserved for regional consumption and are found only exceptionally outside their region of origin. This observation is perfectly illustrated by the bellied pots, intended to contain foodstuffs or to become a cinerary urn, but whose shape lends itself poorly to transport. Thus, the distinctive vases with tronconical belly and handles bent back in the shape of two Rs back-to-back are not found outside the Poitou region; ${ }^{52}$ bulbous, socalled apple-shaped, receptacles do not travel outside their regions of origin in

${ }^{48}$ Berger and Jouve (1980: fig. 4). 49 Moirin (2003).

50

51 See the list drawn up by Rütti (2003:357) and Nenna (2008b), to which must be added recent finds in the excavations of the auditorium of Bordeaux, at Nîmes, and at Fos (underwater find), and a discovery in Asia Minor at Xanthos (unpublished; mission directed by de Courtils, ( 52 Simon-Hiernard (2000: 105-9).
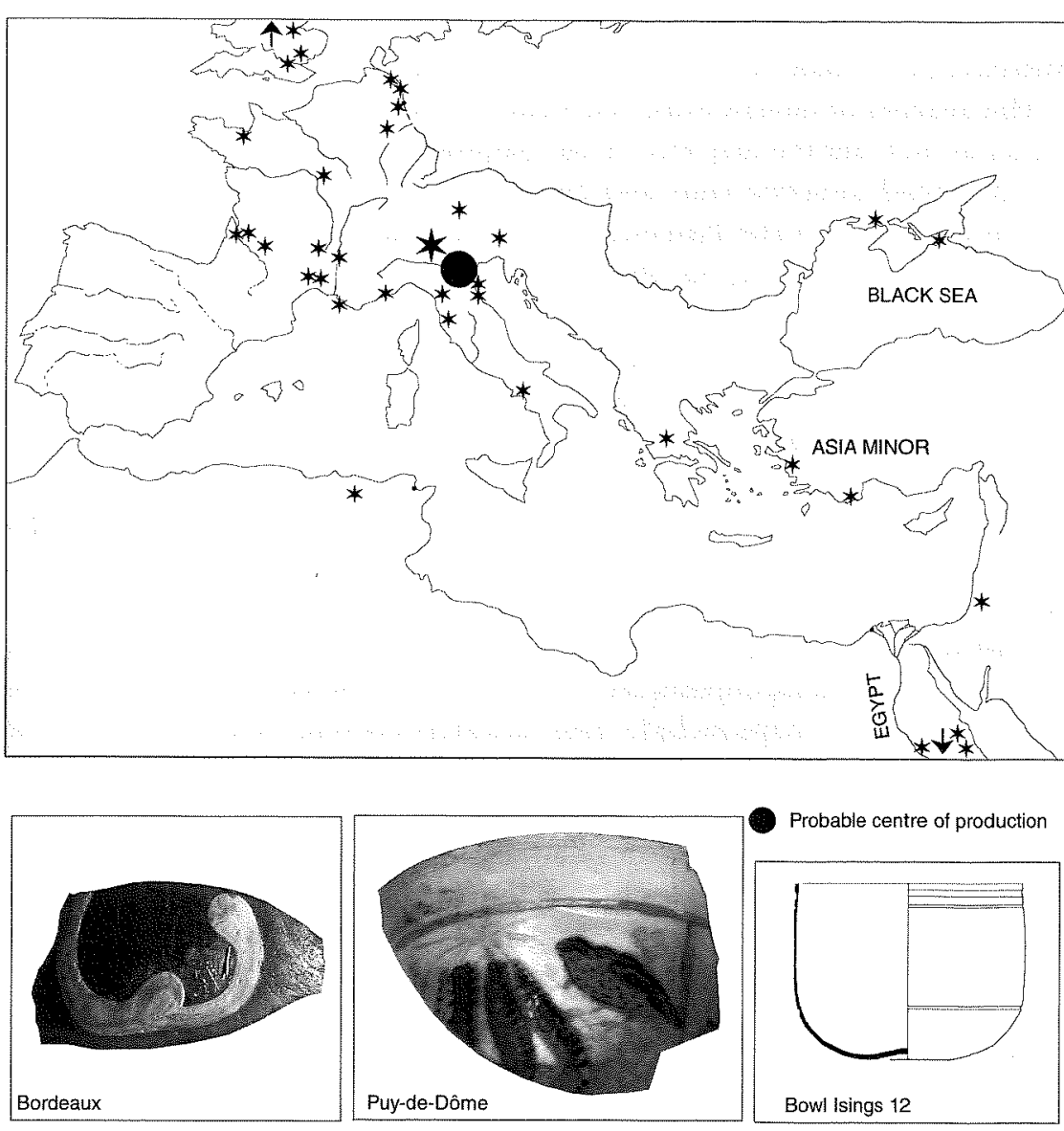

Probable centre of production

Fig. 9.2. Distribution of painted bowls of the first century AD

Normandy or central Gaul, and the Languedocian pots characterized by ring handles never cross the Rhône. ${ }^{53}$

One might have expected to discover in port deposits of the second half of the first century numerous glass containers reflecting a trade in liquid foodstuffs. Common forms such as balsamaria in blue-green glass, used during the first and at the start of the second century AD (types Isings 8 and 28), are found throughout the whole of the western Roman world, including Africa. As these were rare at sites on major trade routes (wrecks, port deposits, entrepôts, and mansiones), it seems that they were not used as containers for the transport of contents, but rather were produced in different places for use in religious

${ }^{53}$ Foy and Nenna (2001: 203) 
ceremonies. They must have contained ordinary perfumes, which could very well have been made at home with local plants.

The analysis of dumps from Narbonne, ${ }^{54}$ Marseilles, ${ }^{55}$ Arles, ${ }^{56}$ or Monaco shows in fact that the majority of the glasswares found belong to tablewares, chiefly ribbed moulded cups and blown goblets, both widely distributed in the western part of the Empire. The former are traditionally attributed to Italian workshops alone, but that has not been demonstrated, and the latter emanate from various production centres. In addition, those vessels lost in the waters of the Rhone at Arles could be interpreted either as merchandise that had arrived from Italy and was heading upstream, or conversely as products of the workshops of inland Gaul, of whose products only a tiny fraction is known.

Our lack of understanding of glass production can go as far as to make us unable to decide between attributing a piece to western workshops or to the eastern Mediterranean; this is especially true for glass of the second half of the second and third centuries that is blown in a colourless glass. At this period, second and third centuries that is blown in a colourless glass. At this period, shops, but they perhaps include other artefacts coming from northern Gaul; they are especially visible in the north and west of Europe and scarcely reach the Mediterranean, where vessels whose precise provenance is unknown circulate. The cargo of glass from the Embiez Ouest wreck includes, besides raw glass, glasswares that could qualify as semi-luxuries: they consist of drinking glasses blown in the same material as the raw glass (glass decoloured with antimony). These forms, which have in common a restrained decoration of appliqué glass threads, all probably come from the same workshop and perhaps from the same region as the raw glass. Their parallels are too few in number and always too dispersed to allow a serious hypothesis to be advanced about their origin. The cylindrical goblets, comparable in some technical details to vessels attributed to several 'continental' workshops, including details to vessels attributed to several 'continental workshops, including
some established in the Rhineland, certainly have a Mediterranean origin that has hitherto eluded researchers. Chemical analyses do not link these glass objects to Syro-Palestinian productions, but remain unable to suggest a preferred hypothesis. This material could also come from Egypt-where this raw material has been identified-Italy, or the Adriatic coasts-where colourless glass is abundant-or even the Greek world, which very quickly produced colourless glass using antimony. In favour of this last hypothesis, there is also a certain resemblance between the profile of ceramic bowls in terra sigillata, called Corinthian relief bowls, and the glass goblets from the wreck, the two being contemporary.

\footnotetext{
${ }^{54}$ Feugère (1992). $\quad{ }^{55}$ Fontaine (2007). $\quad{ }^{56}$ Fontaine (2008).
}

The maritime circulation of glass vessels and of window glass in the course of the third century is illustrated by this Provençal wreck and that of Porticcio on the western coast of Corsica; until now we had been unaware that windows, which are merely simple rectangular panels of glass, were the object of maritime trade. In the Embiez wreck are also found a rarer type of window glass, consisting of large convex glass panels, doubtless intended to be placed on the roof, vault, or domed ceiling of a bath building for overhead lighting. ${ }^{57}$

Of the commerce in glass in late antiquity, we see principally, as with the preceding periods, the luxury pieces. The pieces decorated with umbilical and coloured cabochons, very characteristic of Rheinland workshops, are widely distributed in the neighbouring regions and, in smaller numbers, as far as the Narbonnaise (Arles, Port-Vendres) and the north-east of the Iberian peninsula (Léon). Engraved glass vessels that from their manufacture and iconography are attributable to the productions of the Rheinland, Moselle valley, or Rome are found in Great Britain, Gaul, the Iberian peninsula, and Africa. Do these beautiful objects always reflect a real trade or are they merely souvenirs brought back from travels and notably from pilgrimages to Rome or other holy places in the eastern Mediterranean? The question is equally worth posing for the little glass pendentifs made in Palestine or Syria and considered either as pious souvenirs or as protective amulets. They are found in fact throughout the whole of Europe and in North Africa.

\section{Glass containers}

The majority of glass bottles probably travelled full. They were receptacles for foodstuffs, but also for more costly products: perfumed oils, unguents, and medicaments. These containers are recognized as being objects of trade by their discovery on sites on trade routes, or by a shape reflecting a particular origin, or if they carry a specific stamp.

\section{Underwater finds}

Although glass receptacles are not commonly present in port dumps, they have nevertheless been identified in some wrecks, but it is not always clear how to distinguish cargo from shipboard equipment. No wreck has been found that was carrying glass bottles as its principal cargo. Bottles are only a small complement to the main cargo. The square bottles found on the Lavezzi wreck, and particularly the assemblage of fourteen pieces coming from a scatter at Cap Camarat, illustrate this. The ten unguentaria stowed in a basket,

${ }^{57}$ Foy and Fontaine (2008). 
discovered in the wreck Saint-Gervais 3, are a rare but certain illustration of the import of glass vessels from Baetica. ${ }^{58}$

\section{Eastern Mediterranean forms}

From the middle of the first to the start of the third century AD, the influx of Levantine glass, although less numerous than the Italian products, is more diversified, insofar as bottles become more common. Among these receptacles, traded probably for their contents, one can distinguish several groups. Small mould-blown bottles, decorated with figured motifs in frames, or masks or fruits, a decoration characteristic of the Syro-Palestinian coast, are found in the rich grave goods of the middle decades of the first century $\mathrm{AD}$ in Aquitaine ${ }^{59}$ and Narbonnaise. ${ }^{60}$

Other less luxury vases of different shapes have in common a collar-like rim, made by folding down and up, which identifies them as products of Palestine or Asia Minor of the start of the second century. Relatively numerous in the Rhone Valley (found in tombs, houses, and shops), they prove that exotic perfumes were much sought after in this region. ${ }^{61}$ There is also, in Narbonnaise and along the whole of the western Mediterranean coast, a series of bottles dated from the second and third centuries AD, from Palestine and Cyprus. In the cemeteries of Arles, the abundance of unguentaria of the type De Tommaso 54 is remarkable. ${ }^{62}$ These links with the eastern Mediterranean are perhaps explained by the presence of a community of easterners in this town.

\section{Vessels with stamps}

A certain number of receptacles, of common form and almost exclusively discovered in the western provinces, were stamped during manufacture. The meaning of these very diverse stamps has not been perfectly elucidated, but they probably refer to the producer of the contents or to someone who profited from the sale of those contents: private merchant, town, or the state. In some cases, the stamp might also signify the nature of the contents. A corpus of these stamps, currently in the process of compilation, will enable us for the first time to study their distribution. ${ }^{63}$ This distribution shows that some vessels were intended for local distribution, others for a regional trade, and others still for interprovincial exchange. These vessels were occasionally the

${ }^{58}$ Foy and Nenna (2001: 109). $\quad 59$ Maurin (1978: 123 and figs 152, 153); Chew (1988). ${ }^{60}$ Bel (2002: 417-18). ${ }_{61}^{61}$ Foy (2003b: 100, 107); Roussel-Ode (2008: 296-7). ${ }^{62}$ De Tommaso (1990: 74)

${ }^{63}$ The study launched on the initiative of the Association Française pour l'Archéologie du Verre has produced three volumes: CSMVA (2006a; 2006b; 2011). The results of a comparable research project focused on Italy should soon appear (by the Italian committee of the L'Association Internationale pour l'Histoire $d u$ Verre). object of a trans-Mediterranean commerce from west to east. Imports from the eastern provinces to the western Mediterranean are rare, but are attested, particularly in late antiquity.

Stamped containers appear mainly in the western provinces between the third quarter of the first century and the fourth century AD. The most commonly stamped forms are:

- large vessels, sometimes in thick blue-green glass: bottles and square jars, rectangular and hexagonal bottles, and miniature barrels;

- bottles of a particular shape, narrow and with a square cross section, in glass that is always colourless and very thick; these vases are called 'Mercury bottles' because their stamp often carries the image of the god Mercury.

- small bottles in fine fragile glass intended for the bottling of perfumes; some analyses have revealed traces of vegetable oils (resin or gum). They were hermetically sealed with wax. ${ }^{64}$

The proportion of stamped receptacles in each series is extremely variable. Although no precise count has been established, we can give a quantitative estimate of stamped pieces (Fig. 9.3).

The most numerous are the miniature barrels, dating mainly from the third and fourth centuries. Almost all the examples, with the exception of the pieces made in a very small format, have a circular epigraphic stamp that suggests that these glass vessels were intended for a specific product distributed and consumed in the north-western provinces, because they are never found in southern regions. ${ }^{65}$

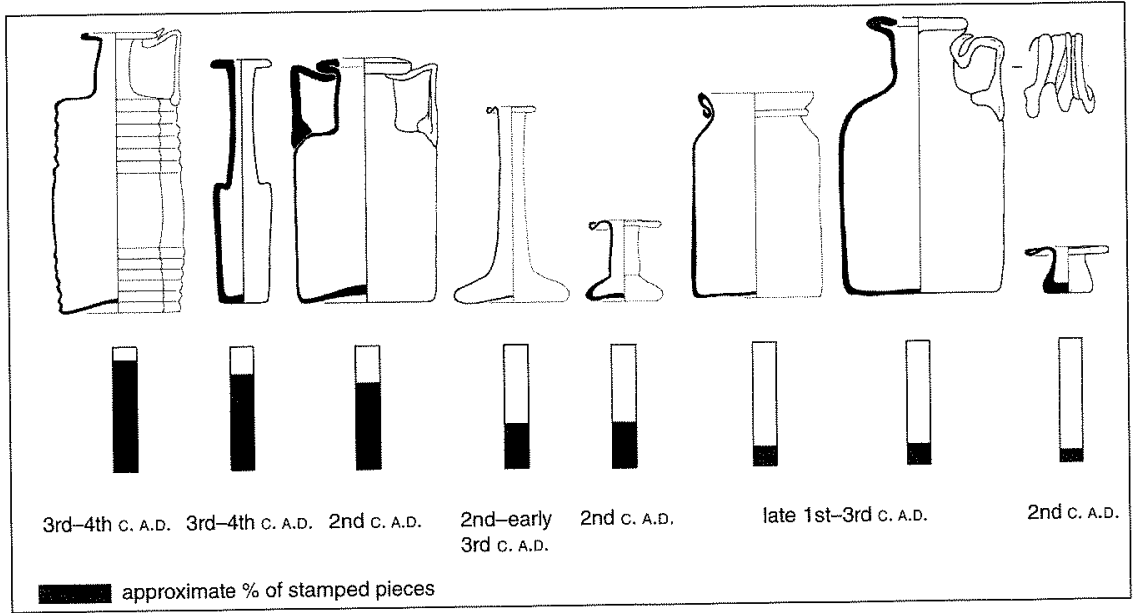

Fig. 9.3. Percentages of stamped vessels in each category

${ }^{64}$ Massart, Fontaine-Hodiamont, and Saverwyns (2004).

${ }^{65}$ Cabart (2006) 
Contemporary with the aforementioned vessels, the Mercury bottles that circulated widely are also very often marked with names, symbols, and abbreviations or geometric motifs ( $70-80$ per cent). The rectangular bottles made in the course of the second century $\mathrm{AD}$, and not common in the Mediterranean regions, are stamped in almost the same proportions, but the stamp is often reduced to a simple lozenge. These three types of glass vessels were made in moulds, which perhaps explains why the stamps are common.

Of the unguentaria intended to contain perfumed oils, two types are usually stamped; some examples of these forms ( $c .25$ per cent), dated during the second century $\mathrm{AD}$ and the Severan period, carry a stamp combining an inscription and a symbol.

The stamps of all these types of glass vessels (miniature barrels, Mercury bottles, rectangular bottles, and unguentaria) are repeated and thus constitute series; variants in the motifs and the templates attest the use of multiple moulds. In a very few cases, the same stamp appears on pieces of completely different shape. A small fraction of the jars and the square bottles (between 10 and 20 per cent) is truly stamped (the concentric circles common on the bases are not considered as stamps). This form, which is the first container to receive a stamp (from the third quarter of the first century $A D$ onward), is nevertheless the most widespread and had the longest lifespan. The stamps are very varied; only those that constitute a series are of interest for the study of trade. We also know a few rare miniature jars with stamps.

To give an idea of the commerce in goods carried in glass containers, I have selected for discussion several marks stamped on jars and square bottles, on rectangular bottles, and on unguentaria. The same demonstration could be made with Mercury bottles; by contrast, the miniature barrels did not circulate in the Mediterranean region.

To illustrate a local market, we can examine several stamps concentrated in one region, a micro-region so to speak (Fig. 9.4). In the west of Gaul and more precisely around Poitiers, the stamps CNAI O and IECD Or IEOD on bottles and square jars ${ }^{66}$ or again the symbol of the double thunderbolt on rectangular bottles, dated to the second century $\mathrm{AD}$, signify local products that only exceptionally travelled outside their region of origin; ${ }^{67}$ a single example is known at Arles. ${ }^{68}$ The same observation could be made regarding the stamp LMT, perfectly concentrated in three towns in the north-east of the Iberian peninsula: Braga, Astorga, and Lugo. ${ }^{69}$ The same type of commerce can again be deduced from the distribution map of three stamps on unguentaria found in Narbonnaise, but uniquely concentrated in the Rhône valley. The name VALERIAN around a palm, encountered six times, the incompletely deciphered stamp CORICO [-] or again the name LIZA/MAM indicate the existence of

${ }_{66}^{66}$ Cabart, Foy, and Nenna (2006). $\quad{ }_{67}^{67}$ Moirin (2006). $\quad{ }^{68}$ Foy (2006). ${ }^{69}$ Cruz (2009: ii. 236).
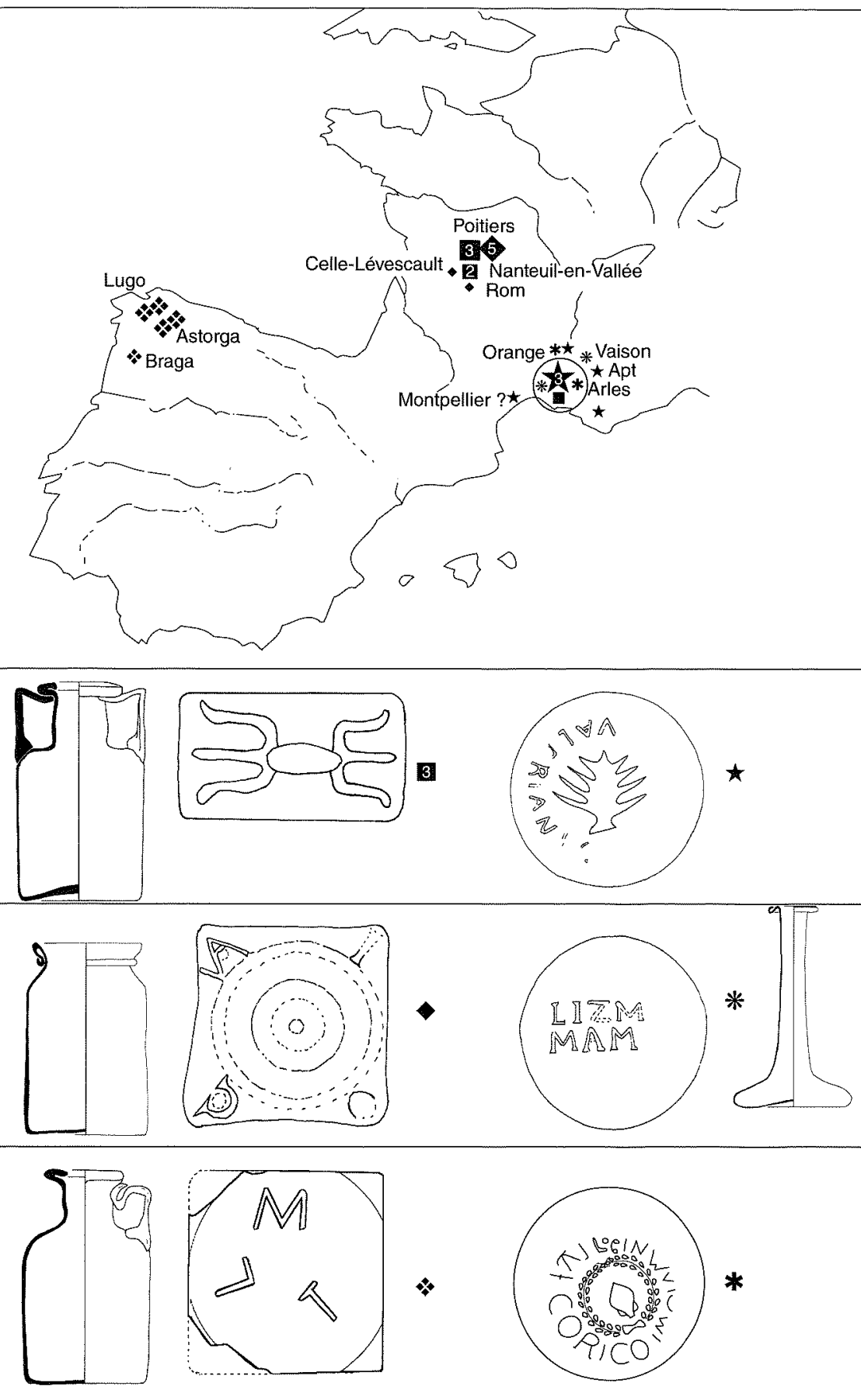

Fig. 9.4. Stamped vessels attesting local trade 
workshops making bottles, and also aromatic substances, which were hardly distributed beyond an area bounded by Arles, Apt, and Orange.

The Iberian and Italian evidence provides examples of the distribution of receptacles in glass within a restricted perimeter, but much larger than the preceding examples (Fig. 9.5). One notes, in effect, that some ten square bottles stamped LLF and LTT are found only in the western half of the Iberian peninsula. ${ }^{70}$ Other pieces present the unusual image of a squirrel gnawing a nut; we do not know their origin: the animal motif is similar to several stamps found in Spain, ${ }^{71}$ but the findspots suggest production in northern Italy. Four finds, made at Zelbio near Lake Como, ${ }^{72}$ at Chur in Switzerland, ${ }^{73}$ and at Faimingen in Raetia, ${ }^{74}$ point to a commerce of limited radius but going beyond a purely local or micro-regional framework. Likewise, the bottles from northern Gaul stamped NASSOMA or MANUSSO ${ }^{75}$ seem to reflect regional consumption. The stamps CCAA and CCCP, which refer perhaps to cities (see below), are very concentrated in the valley of the Rhine and also provide excellent examples of a short- or medium-distance distribution. ${ }^{76}$ The small stamped unguent jars are not very common: the only ones found have a stamp with a wreath and are found in a distribution between Tongres, Reims, and Augst. The production or packaging of the balms or ointments they contained can probably be located in Lower or Upper Germany during the course of the second century. In these regions, no original stamp is known on unguentaria, which does not indicate the absence of traders in cosmetics. These costly products (unguents, aromatic mixtures, eye lotions) were packaged in these little jars and particularly in Mercury bottles with various stamps. But, while the small vessels scarcely travelled, the Mercury bottles of the third and beginning of the fourth century $\mathrm{AD}$, originating from different centres in the Rhineland and Italy (the Po Valley, and Rome), were the object of longdistance trade. This very widespread distribution and the absence of a systematic classification of the Italian finds do not allow us clearly to identify the centre of production of the most common stamps. By way of example, one could cite the stamp GFHI, common in the Rhineland, ${ }^{77}$ but often found in Italy and notably at Rome ${ }^{78}$ reported also from Pannonia, and scattered throughout the whole of Gaul as far as the Mediterranean. ${ }^{79}$

Long-distance trade in probably edible commodities carried in the square bottles is traceable through the distribution of particular stamps, although these are limited in number (Fig. 9.6). Imports from Italy and Spain are thus

\footnotetext{
Price (2006); Cruz (2006). $\quad{ }^{71}$ Price (2006: no. E-CAR 037, 038).

Taborelli (1995: fig. 7). $\quad{ }^{73}$ Amrein (2006: no. CH126).

D-RA 105, 106) - 75 Cabart Foy, and Nenna (2006).

${ }^{6}$ Follmann-Schulz (2006: 82); Sablerolles (2006: 29-30).

77 Follmann-Schulz (2006).

Sternini, Agricoli, and Mazzei (1997: 60); Del Vecchio (2004: 41).

Arveiller (2006)
}
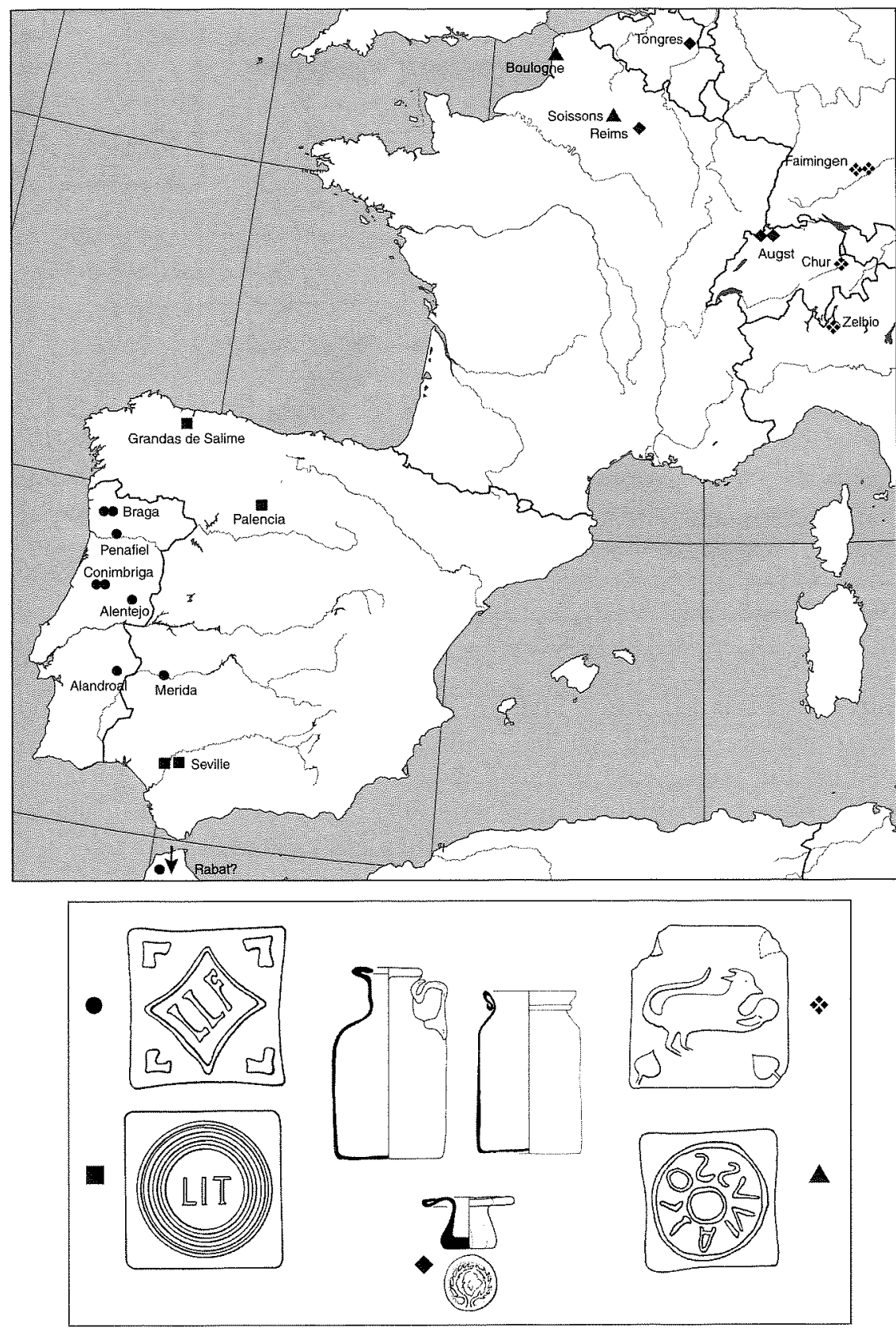

Fig. 9.5. Stamped vessels attesting regional trade 


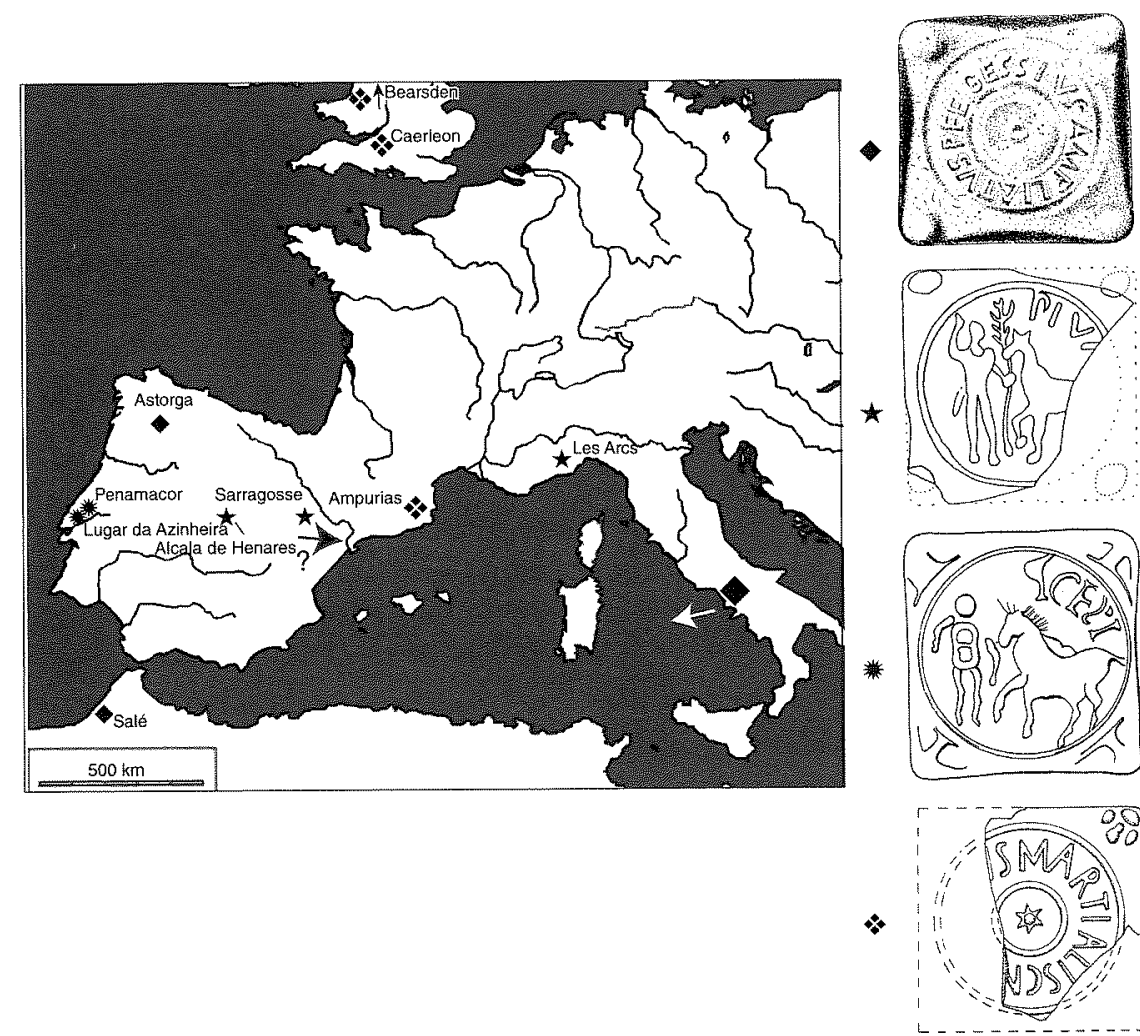

Fig. 9.6. Stamped vessels attesting inter-regional trade

identifiable. The stamp P. GESSIVS AMPLIATVS, one of the earliest, is concentrated in Italy in the Vesuvian region. Outside this area, it is only known from Mauretania Tingitana (Salé/Sala) and in north-east Spain at Astorga. ${ }^{80}$ A stamp representing a winning charioteer and his horse appears in two variants in the Iberian peninsula. One piece, comparable to an example with the name pius reported from Alcalá de Henares ${ }^{81}$ and Zaragoza, ${ }^{82}$ was found on the Provençal coast and probably attests a commercial link with Spain in the course of the second century. ${ }^{83}$ We cannot, however, say whether the stamp GN ASINIVS MARTIALIS found on square and rectangular bottles of the second century reflects imports from Spain towards Britain or a movement in the opposite direction. ${ }^{84}$

${ }^{80}$ Cruz (2009: ii. 308). $\quad{ }^{81}$ Ludi romani (2002: 211).

${ }^{82}$ Unpublished piece, information from E. Ortiz Palomar; study in progress.

${ }^{83}$ Cabart, Foy, and Nenna (2006: 99).

34 Price (2006: 291); RIB II.2, 2419.106 and 107
Two other types of square bottles that probably emanate from important firms were the object of a more dense and probably more regular commercial traffic, because these objects form a fuller series (Fig. 9.7). These interprovincial transports, however, almost never link the countries of the Mediterranean with the northern provinces. For a long time the distribution of the stamp formed of the letters AF inscribed in a $\mathrm{Q}$ has attracted attention. ${ }^{85}$ This stamp, which presents several variants, as do the majority of the others, appears on a score of pieces of which half are from Britain, the remainder being from the Low Countries and the Rhineland. Some isolated pieces, known from Avenches ${ }^{86}$ and in the centre of Gaul (Bourges, Saint-Paulien), ${ }^{87}$ seem to indicate that the contents of this container were appreciated by a large part of the population. Still more numerous, but emanating this time from a trader established in northern Italy, the receptacles (bottles and square jars) stamped C SALVIUS GRATUS, probably of the very beginning of the second century $A D$, were distributed in Italy through the Po Valley and the Adriatic (Italy, Slovenia). In a still more intense fashion, they were sent to the north of the Alps (Switzerland, Austria, Germany), chiefly in Raetia, where the greatest number of pieces are known, to the point where it has sometimes been seen as another production centre. ${ }^{88}$ The variety of moulds used makes it difficult to count the fragments, but more than fifty pieces may be registered. Mostly traded by river (Po and Danube) and overland routes, but also by sea (the Adriatic), the contents of these vessels did not interest-or only very minimally-the Mediterranean market. Two Provençal pieces are perhaps the most southerly and at the same time the most westerly examples. ${ }^{89}$ To finish this rapid tour d'horizon of the trade in stamped square bottles, it is necessary to mention the most distant imports. Very few glass items made in the eastern provinces in the imperial period seem to have been stamped. The three receptacles discovered in Narbonnaise and on which are stamped exotic animals (elephant and dromedary), accompanied by an inscription in Greek, could indicate imports from the eastern provinces or Africa (?) in the first half of the second century AD. ${ }^{90}$ Other finds, in Narbonnaise but also in Italy, also carry Greek inscriptions: they reflect late antique productions possibly situated in Asia Minor. ${ }^{91}$

Bottles for aromatic and medicinal substances, unguentaria, and Mercury bottles are the glass items that travelled the most. One could say, with some simplification, that the Mercury bottles embody the commerce in these luxury products from Germany and northern Italy, while the unguentaria essentially

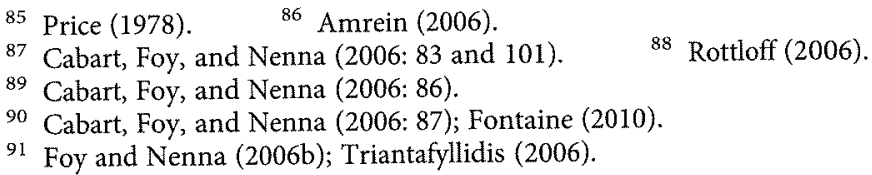



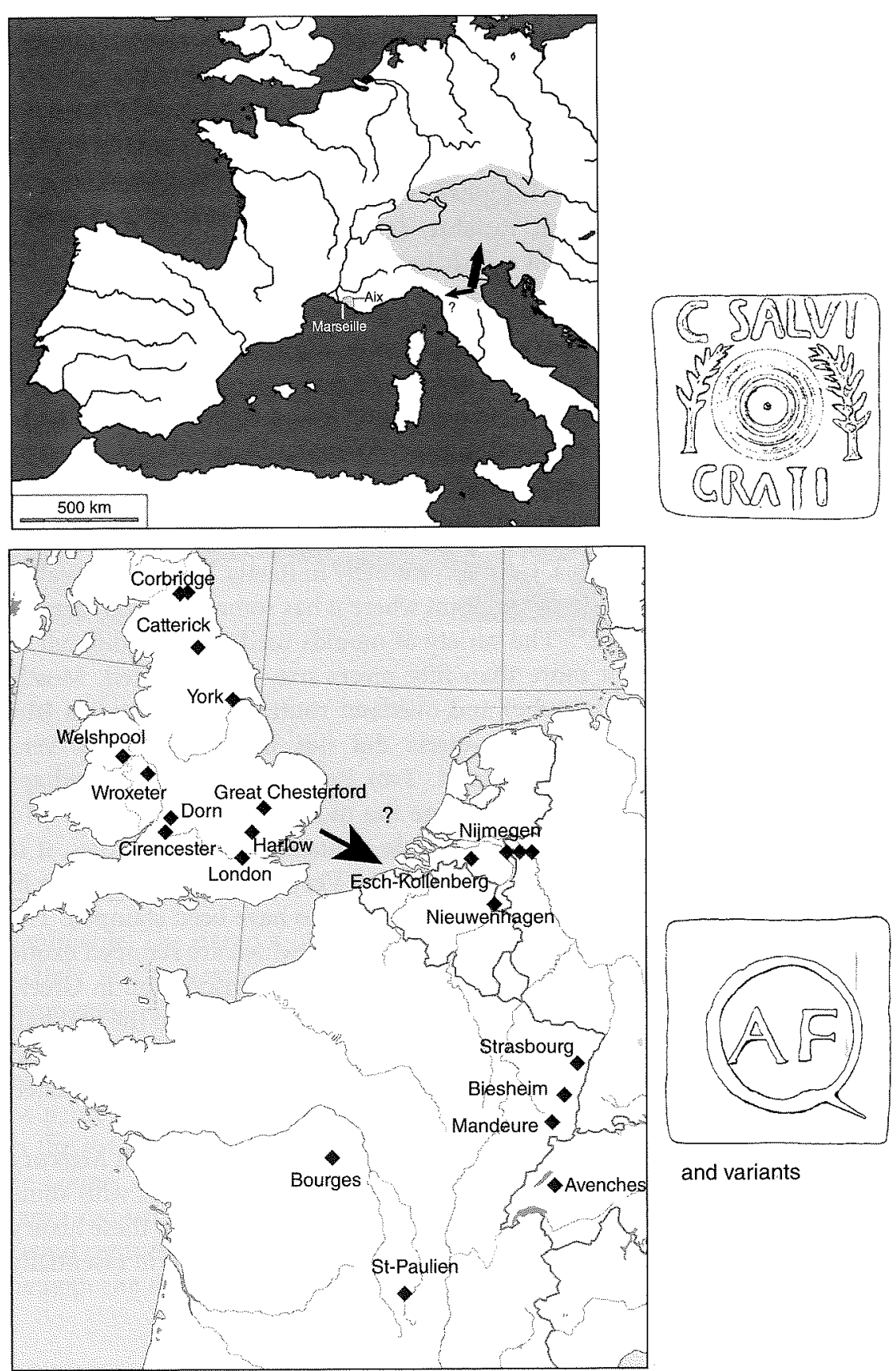

and variants

Fig. 9.7. Stamped vessels attesting inter-regional trade from northern Italy (top) and Britain (below) reflect distribution from Italy and principally the region of Rome. ${ }^{92}$ The two types of container cover geographical areas that intersect, but the unguentaria are naturally more abundant in the regions close to Italy. We will try here to provide a survey of the market for these cosmetics through the distribution of some stamps on unguentaria.

Perfume bottles made in northern Italy were intended, like the bottles of Caius Salvius Gratus, for a market oriented towards the north: the findspots of pieces stamped with the letters QDE/LPF or V D flanked with palms ${ }^{93}$ clearly reflect the usual commercial circuits. Very common and widespread in northern Italy from Turin to Verona and Urbino, these glasswares are recognized as regional products, both by their stamps and by their bell-shaped profile. Their distribution towards the north, outside Italy, is less important but nevertheless marked by finds at Lubiana and Ovilana in Upper Austria ${ }^{94}$ and at Cologne. ${ }^{95}$ The discovery of large receptacles bearing apparently the same stamp (expanded as Q DANIVS EVHELPISTVS) prompts one to wonder if the same product was also traded in larger containers, or if the same enterprise traded different commodities under the same name. ${ }^{96}$

Completely different is the route taken by perfumed oils produced or bottled probably in central Italy (Fig. 9.8). The most common STAMPS, CSC with a cock, SPS CAF and SPS CPD surrounding an image of Athena or Mercury, A. VOLVMNI IANVARI and CN.A.ING.V.A.V.M., known from several tens of examples, are chiefly found in Italy, but were traded throughout the whole of Gaul (mainly in Narbonnaise), part of Germany, and Britain; curiously, the Iberian peninsula was not involved in this market, although it probably used maritime routes. The routes along which the stamp PR.MANC.AR was distributed appear by contrast different, since they seem to link the south of the Iberian peninsula to Italy and are rare outside these countries; it has, however, been pointed out that the Spanish pieces have a conical profile, specific to the products of Baetica ${ }^{97}$ should one conclude from this that the same stamp was applied in workshops that were very distant from each other? The place of production and the mode of distribution of the bottles stamped C. LVCRETI FESTIVI are still less certain. This not particularly common stamp is, paradoxically, extremely widely dispersed. It is present in Italy, ${ }^{98}$ in Britain, ${ }^{99}$ at Trier, ${ }^{100}$ in the Parisian region, and at Arles (unpublished discovery); the conical profiles of sufficiently

${ }^{92}$ Some rare stamps found only in Britain (RIB II.2, 2419.87 and 88 ) or distributed in Germany and Gaul but apparently absent from Italy (stamp M...S.C.M.V known in Belgium: Vorsen, Tongres; in Germany: Xanten; in France: Besançon, Tours, Méasne, Vaiso sum, Lyons, and Autun) might originate in the nothern provinces.

(1998: 123, no. 4); Mandruzzato and Marcante (2007: no. 227).

${ }^{94}$ Glöckner (2006: no. AUS 71). $\quad{ }_{95}$ Fremerdorf (1961: 49).

enna (2006: 202-3).

99 Cambridge: RIB II.2, 2419.102. ${ }_{100}$ CIL XIII, 10025.8 . 


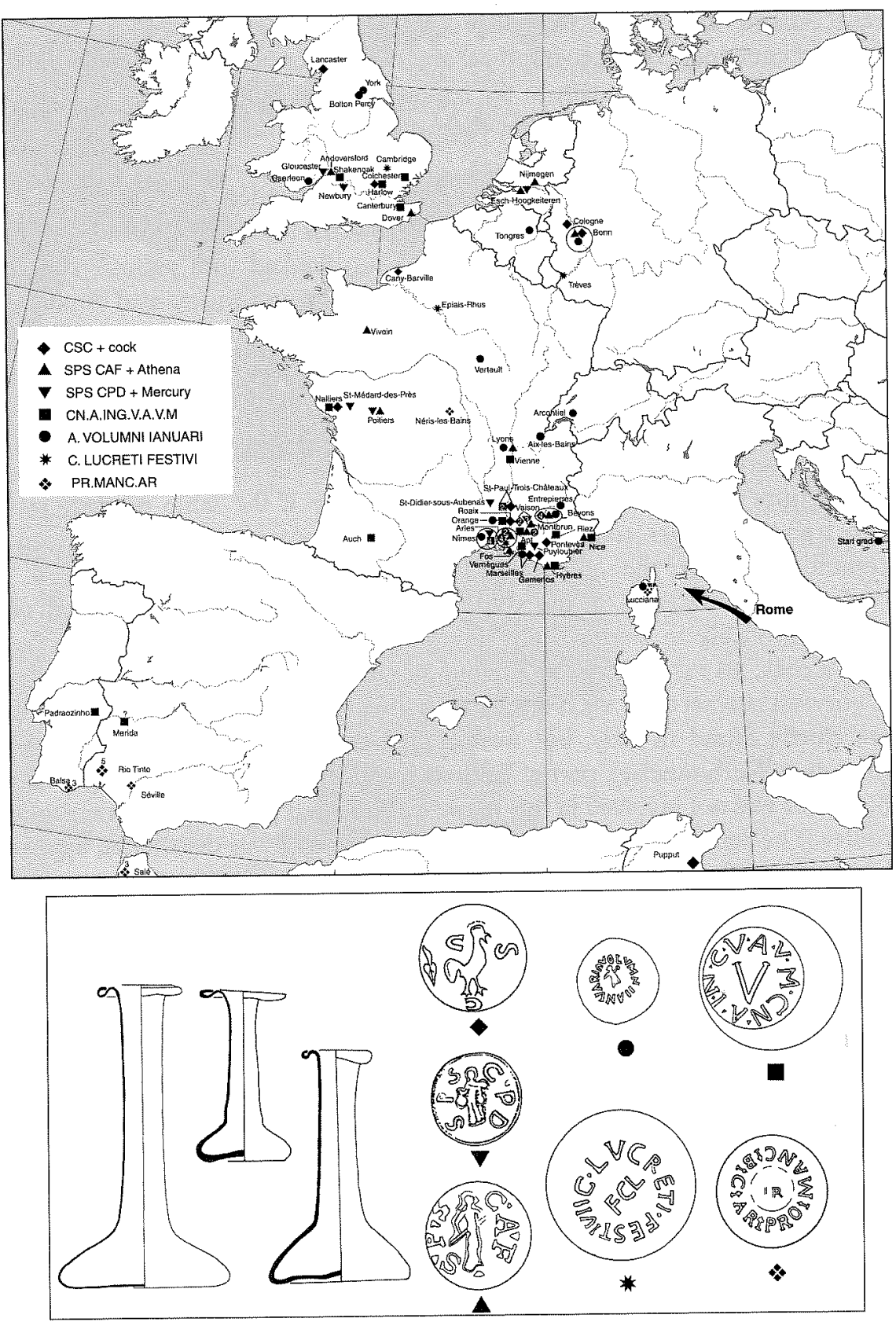

Fig. 9.8. Distribution, from Italy, of stamped unguentaria well-preserved bottles resemble items from Baetica, but no find from that province supports the hypothesis that they actually came from there.

Many scholars have wondered about the meaning of these very different stamps. ${ }^{101}$ The names of people, on the jars and square bottles, on the miniature barrels, both of them being early in the series and dating to the middle of the first century $\mathrm{AD}$, and the unguentaria, preceded by EX $\mathrm{O}$, such as EX OF(FICINA) TITIANI HYCINTHI ${ }^{102}$ or EX OFF(ICINA) M(ARCI) EPR( ... CLEM(ENTIS) 103 or followed by F or FECIT, such as FELIX FECIT ${ }^{104}$ or CHRESIMUS FECIT, ${ }^{105}$ unquestionably refer to the owner of a workshop. But what type of workshop? It is generally agreed that this is not the glass workshop, but the centre producing the contents. C(aius) Salvius Gratus, Gn(aeus) Asinius Martialis, Q. Danius Euhelpistus, or A(ulus)Volumnius Ianuarius, to cite only some of the most common tria nomina, would thus be the producers or the traders of the foodstuffs or cosmetics bottled in these vessels of glass, a fragile material to be sure, but perfectly watertight and odourless and thus well suited to these contents.

The state might be the proprietor, the producer, or the controller of the perfumed oils and other costly substances traded in these stamped bottles. Stamps referring to state authorities have been listed: ${ }^{106}$ PATRIMONI and its derivatives are the most common and most widespread stamps; they are found on unguentaria of variable sizes and shapes, of which the majority certainly issue from Italian workshops, but the close study of variants and profiles of the glasswares that carry them could help in circumscribing more narrowly the places of production and the controlling offices. Thus it is clear that the stamp PATRIMONI, formed of well-stamped letters, thick and regular, generally encircles a Victory that is not very legible. This stamp occurs most commonly on a squat bottle, of variable size, in relatively thick and almost colourless glass. This very widespread form is found throughout the whole of Italy and especially at Rome, in Narbonnaise, at Tarragona, ${ }^{107}$ in Switzerland, ${ }^{108}$ at Trier, ${ }^{109}$ and at York. ${ }^{110}$ There exists, however, a derivative stamp, probably specific to the northern provinces as the location of the five discoveries seems to prove: on these large bottles, PATRIvMONIUM surrounds a small figure represented in motion, probably Mercury (Fig. 9.9).

In addition to PATRIMONI and its derivatives, there are other state stamps that indicate either that the contents come from imperial estates or that they are controlled and taxed by the state: VECTIGAL PATRIMONI, VICTORIAE AUGUSTOR(UM) FEL(ICTTER) V(ICTORIAE) P(ARTHICAE) and PRO.MANC.B.C.AR (already mentioned), are

$$
\begin{aligned}
& { }^{101} \text { Frova (1971); Taborelli }(1982 ; 1983) . \quad 102 \text { Whitehouse (2003). } \\
& 103 \text { Foy and Nenna (2006a: } 146) \text { 104 Sablerolles (2006: 16-17). } \\
& 105 \text { RIB II.2, 2419.101. }{ }_{106} \text { Sternini (1993: 86-8). } \quad \text { 107 Price (2006: 299). } \\
& \text { 108 Amrein (2006). }{ }^{109} \text { Goethert-Polaschek (1977: no. 74). } \\
& { }_{10} \text { RIB II.2, 2419.131. }
\end{aligned}
$$



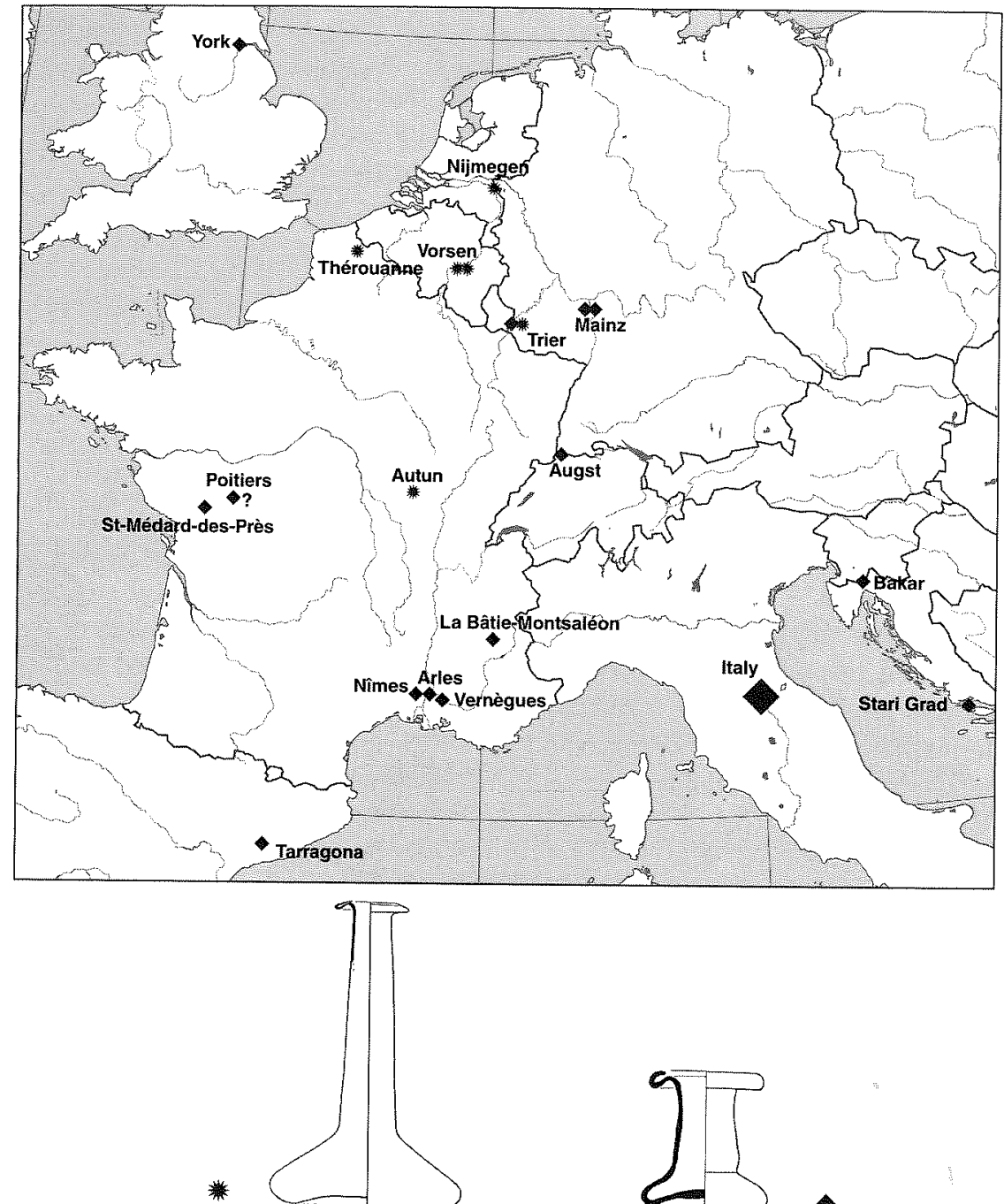

Northern Gaul
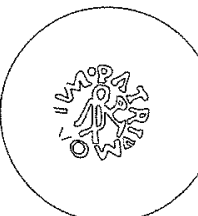

Fig. 9.9. Distribution of two types of unguentaria bearing two variants of the state stamp PATRIMONI emanating from two centres: Italy and probably northern Gaul the most common. The stamp AVG, like that which is visible on Dressel 20 amphorae, is unique insofar as it is present only, and in very great quantities, in the Iberian peninsula (a hundred examples) ${ }^{111}$ and in northern Morocco. One might have expected that these bottles, heavily concentrated in the Rio Tinto region, which was well connected to long-distance trade routes, might have travelled beyond the Iberian peninsula. It seems, on the contrary, that the perfumed oils of these unguentaria were almost exclusively consumed in Baetica. One might suggest that we are perhaps dealing with aromatic substances from the eastern provinces, brought by those who came in search of the minerals of Baetica, and that they would have been repackagd in the stamped bottles. The perfumes could have come from imperial estates or indeed private ones. In this latter case, one would imagine that a tax was levied by the imperial authorities.

Some complex stamps carry indications, either spelled out or in the form of a monogram, naming the town where the product was bottled or taxed: PATRIMONI F(ISCI) RATIONIS/RAVEN(NATIUM), dated to the third century AD. J. Price, ${ }^{112}$ expanding the stamp pro(CVRATORIS) MANC(IPIORUM EX) B(ONIS) $C$ (ADVCIS) AR(VCCI or VAE), found in Baetica, suggests that the contents, coming from a property acquired by the state, were traded under the authority of a procurator-the letters AR referring to a town near Rio Tinto. The letters ( $\mathrm{s}, \mathrm{V}$, or $\mathrm{AF}$ ) placed in the middle of the very widely distributed stamp with the circular inscription CN.A.ING.V.A.V.M. (Fig. 9.8) have been seen as a reference to a town that might be either the place of production, bottling, or sale of the product contained, or even an administrative centre. Some stamps refer directly to a town: the letters placed in the angles of some square bottles could be the abbreviation of the name of a colony. It has been proposed that the letters CCAA (Colonia Claudia Ara Agrippinensium) should be identified with Cologne. ${ }^{113}$ Other common stamps also from the Rhineland such as CCCP ought therefore to have a comparable significance. This interpretation would imply that the trade in certain products was under the control not of an individual or of a private firm, but of a city-unless the reference to the town is merely a mention certifying the origin and consequently the authenticity of the product. The interpretation of these stamps is, however, disputed. ${ }^{114}$

One might think that the stamped unguentaria contained the most popular aromatic substances; these commodities travelled, but perhaps no more than those in containers that were anonymous or originally distinguished by a label. No perfume bottle from the eastern provinces is stamped. Aromatic mixtures might arrive in bottles with a tag or even in phials whose wax stoppers were stamped. Perhaps the shape of the container, identifiable to the eyes of connoisseurs, could guarantee the origin. Other perfumes might also have

${ }_{111}$ Price (1977; 2006). ${ }_{112}$ Price (1977).

113 Follmann-Schulz (2006: 82) ${ }_{114}$ Sablerolles (2006: 29-30). 
been imported in large containers, and then rebottled in the stamped unguentaria.

The content of the large glass containers is unknown. The large square bottles (mid-first century to end of the second century $\mathrm{AD}$ ), the rectangular bottles (second century $\mathrm{AD}$ ), and the miniature barrels (mainly third century) were used in numerous areas, but rarely (square bottles) or never (miniature barrels) in the Mediterranean regions. All these vessels, made in moulds, are found in several formats; their method of manufacture encouraged their standardization and the calibration of their capacity to achieve precise volumes. The miniature barrels, chiefly in use in the third and fourth centuries, seem to replace the square and rectangular bottles used at the end of the first century and throughout the second century. One can only conclude from this that they were all intended to contain the same product. The miniature barrels are poorly suited for transport, as they are made of thin glass, much more fragile than that of the earlier bottles. The shape of the miniature barrels naturally suggests a drink. Several analyses performed on the preserved contents show, however, that it was not wine nor another alcoholic beverage. ${ }^{115}$ The oleaginous substances detected are difficult to interpret, ${ }^{116}$ but, if one admits that this distinctive packaging, this sort of 'design', reflects a wish to indicate a specific product, it could only be a foodstuff commonly consumed from Britain to Germany. The miniature barrels are extremely widespread in the north of Gaul and the Rhineland, where several workshops have been identified through the distribution of the main stamps on these vessels. By way of example, the stamp M Q CASI NOCTVRNI, one of the oldest (end of the second century $\mathrm{AD}$ ?), is from Burgundy, COM FOR FRON originates in north-eas France, the STAMP CEREI ATTICI is found mainly in eastern Gaul, ${ }^{117}$ while the stamp ECVA emanates from the Rhineland glass workshops of the fourth century $A D .{ }^{118}$ These marks probably served to distinguish the origin or the quality of the products, which were mainly consumed regionally, although imports from northern Gaul to Britain are significant, ${ }^{119}$ and a Rhineland miniature barrel reached Lyons. ${ }^{120}$

The residue analyses that have been performed have not been able to identify with certainty the principal contents of the miniature barrels. The fatty materials discovered could be traces of condiments preserved in oil, or perhaps even garum made from fatty fish (?). Given the enormous capacities of some fish salting and garum factories on the coast of northern Gaul that are now known, one could imagine that others might also have served regional demand.

Bottles and square jars travelled much less than perfumes. Only a few pieces were stamped with inscriptions that refer to the issuer (producer or merchant)

\footnotetext{
115 Mahéo (1990: 276). $\quad{ }_{116}^{116}$ Gaitzsch et al. (2000: 128). $\quad{ }_{117}^{117}$ Cabart (2006).

${ }^{119}$ Price $(2011: 26-7)$
}

120 Foy (2011: 89). For a more synthetic approach, now see Foy (2015). of the contents, or were stamped with extremely varied motifs whose significance remains unclear. Were these symbols, made of geometric or figured motifs, the logo of an enterprise or even a direct allusion to the product bottled inside? If the images of a fish and an anchor visible on containers from the Iberian peninsula allude to the products of the sea, many others (representations of objects or animals) remain incomprehensible. In some very rare cases, we have been able to relate stamps on amphorae and on glass. The stamp LIT visible on olive-oil amphorae from Baetica and on some square bottles found in the south of Spain might indicate that the containers in glass were also intended for olive oil. The extreme diversity of the stamps of which only some form a series allows one to imagine multiple products and origins, and, by consequence, numerous people employed in the production and commerce of these foodstuffs. This situation is very different from that which one imagines for the industry and trade in cosmetics, dominated mainly by some private and state enterprises. But clearly we do not know the importance of this commerce, which is impossible to grasp through the unstamped vessels that are also difficult to differentiate by shape alone.

\section{CONCLUSIONS}

Raw glass was the object of long-distance trade throughout the whole of antiquity. Chemical analyses enable the identification of the Syro-Palestinian or Egyptian origin of some of this semi-finished material. These exchanges express the dependance of the secondary glassblowing workshops in the west on eastern sources. This heavy material, probably with a strong value-added element, could have been a very popular cargo.

Manufactured glass items also entered into the circuits of trade. The circulation of luxury glasswares is clearly the most visible, but typological analysis, and certain contexts of discoveries (wrecks and port sites) show that other common tablewares also travelled.

The distribution of products bottled in glass containers is harder to identify through the same criteria, but the stamps reveal objects intended for a local clientele, a regional market, and those that entered into the circuits of longdistance trade. They could also lead one to think that certain products were traded privately and that others were controlled by state authorities; certain interpretations suggest also that cities sometimes played a role in the production, the trade, or the guaranteeing of the origin of the commodities bottled in the glass vessels.

Aromatic and pharmaceutical substances appear as products that travelled the furthest, but also as the products on which the imperial authority 
intervened, as witness the very great abundance of the stamp PATRIMONI and its derivatives applied on unguentaria. By contrast, the stamps on Mercury bottles-which probably held a similar and highly profitable content-show no signs of connection with an imperial authority.

This sketch of the trade in glass in antiquity leaves much room for doubt and questions. The interpretation of distribution maps, the resolution of stamps, whether on glass or on other materials, are never certain and can never command unanimity. The data on which research on the distribution of glass is based remain particularly thin, disparate, and scattered, and ou ignorance of the location of most of the production centres constitutes a major obstacle. Considerable progress has nevertheless been made since the mid-1990s in understanding the sequence of production and circulation of glass thanks to the results of archaeometry, the diversification of archaeological excavations (primary production centres, secondary glassblowing work-

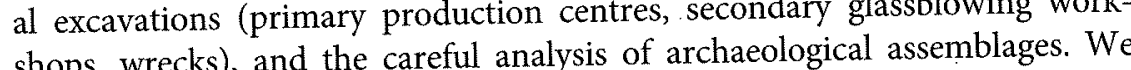
shops, wecks a ma the archaeogical documentation easily accessible to systematic exploitation; setting side by side the images, sharp or fuzzy, that we systematic exploitation; setting side by side the images, sharp or fuzzy, that we have of the trade routes of different ancient material is also necessary to try to assess the place of glass, in all its forms (architectural material, tableware, ornaments, and containers) in the ancient economy. Objectively, glass represents only a tiny fraction of the mass of commodities traded, but the market value of certain glass vessels and of commodities that one chose or found necessary to bottle in a stable material should not be underestimated.

\section{REFERENCES}

Amrein, H. (2001). L'Atelier de verriers d'Avenches: L'Artisanat du verre au milieu du $1^{\text {er }}$ s. apr. J.-C. (Cahiers d'Archéologie Romande, 87). Lausanne.

Amrein, $\mathrm{H}$ (2006) 'Marques sur verre attestées en Suisse', in CSMVA (2006b), 209-43 and pls $60-3$.

Arveiller, V. (2006). 'Les Bouteilles Mercure', in CSMVA (2006a), 125-32

Vel, (2002). Pratiques funéraires du Haut-Empire dans le midi de la Gaule: La Nécropole gallo-romaine à Saint-Paul-Trois-Châteaux (Monographies d'Archéologie Méditerranéenne, 11). Lattes.

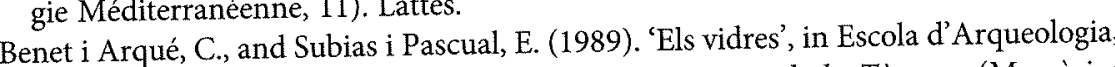
Benet i Arqué, C., and Subias i Pascual, E. (1989). 'Els vidres', in Escola d Arqueologia,
Un abocador del segle V D. C. en el Fòrum provincial de Tàrraco (Memòries d'excavació, 2). Tarragona, 329-49.

Berger, L and Jouve, M. (1980). 'Un fragment de verre à ruban d'or découvert à Bethisy-Saint-Martin (Oise)', Revue archéologique de l'Oise, 18: 9-13.

Boucharlat, R. (1989). 'Documentation provenant de sites hellénistiques de la PéninBoucharlat, R. (1989). 'Documentation provenant de sites hellenistiques de la Penin-
sule d'Oman', in T. Fahd (ed.), L'Arabie préislamique et son environnement historique et culturel. Leiden, 109-26.
Brill, R. (1988). 'Scientific Investigations of the Jalame Glass and Related Finds', in G. Weinberg (ed.), Excavations at Jalame: Site of a Glass Factory in Late Roman Palestine. Columbia, 257-94.

Brun, J.-P. (2003). 'Sur les pistes caravanières, le verre. Le désert occidental égyptien', in Foy (2003b), 148-9.

Cabart, H. (2006). 'Les Barillets', in CSMVA (2006a), 149-89 and pls 86-120.

Cabart, H., Foy, D., and Nenna, M.-D. (2006). 'Les Bouteilles et pots carrés', in CSMVA (2006a), 73-107 and pls 4-37.

Chew, H. (1988). 'La Tombe gallo-romaine de Saintes: Nouvel examen du matériel', Antiquités nationales, 20: 35-61.

Cosyns, P., Vanderhoeven, A., Vynckie, G., Janssens, K., and Schalm, O. (2005). 'Two Fragments of Mold-Blown Glass Beakers with Greek Inscriptions from Tongeren (Belgium)', Journal of Glass Studies, 47: 179-83.

Cruz, M. (2006). 'Marques sur verres antiques du Portugal', in CSMVA (2006b), 325-47. Cruz, M. (2009). 'O Vidro no Noroeste Peninsular: Um olhar a partir de Bracara Augusta'. 3 vols. Thesis, University of Minho.

CSMVA (2006a). Foy, D., and Nenna, M.-D. (2006) (eds). Corpus des signatures et marques sur verres antiques, i. La France. Aix-en-Provence and Lyons.

CSMVA (2006b). Foy, D., and Nenna, M.-D. (2006) (eds). Corpus des signatures et marques sur verres antiques, ii. Pays-Bas, Belgique, Luxembourg, Allemagne, Autriche, Suisse, Slovénie, Hongrie, Croatie, Espagne, Portugal, Maghreb, Grèce, Chypre, Turquie, mer Noire, Proche-Orient, Égypte, Soudan, Cyrénaïque, France (Addenda). Aix-en-Provence and Lyons.

CSMVA (2011). Foy, D., and Nenna, M.-D. (2011) (eds). Corpus des signatures et marques sur verres antiques, iii. Grande-Bretagne et addenda (Pays-Bas, France, Allemagne, Suisse, Croatie, Espagne, Portugal, Grèce, Turquie, mer Noire, ProcheOrient). Aix-en-Provence and Lyons.

Del Vecchio, F. (2004). Collezione Gorga vetri II: Le produzioni della prima e media età imperiale soffiate con l'ausilio di matrici. Florence.

De Tommaso, G. (1990). Ampullae vitreae: Contenitori in verto di unguenti e sostanze aromatiche dell'Italia Romana (I sec. A.C.-III d.C.). Rome.

Dodero, E. (2008). 'Il vetro cammeo nella prima etá imperiale: Una sintesi con breve notizia di alcuni frammenti inediti del Thorvaldens museum di Copenhagen', Facta, 2: $39-60$.

Feugère, M. (1992). 'Un lot de verres du $\mathrm{I}^{\text {er }}$ siècle provenant du port de Narbonne (Aude) (sondages 1990-1992)', RANarb. 25: 177-206.

Feugère, M., and Leyge, F. (1989). 'La Cargaison de verrerie augustéenne de l'épave de la Tradelière (Iles de Lérins)', in M. Feugère (ed.), Le Verre préromain en Europe Occidentale. Montagnac, 169-76.

Follmann-Schulz, A.-B. (2006). 'Römische Gläser mit Buchstabenmarken im Rheinischen Landesmuseum Bonn', in CSMVA (2006b), 81-109.

Fontaine, S. (2007). 'Le Verre d'un dépotoir portuaire du Haut-Empire à Marseille (Place Jules Verne): Premiers résultats', Bulletin de l'Association française pour l'Archéologie du Verre, 12-21.

Fontaine, S. (2008). 'Le Commerce du verre antique dans l'axe rhodanien: L'Apport des fouilles subaquatiques d'Arles (Bouches-du-Rhône)', Bulletin de l'Association française pour l'Archéologie du Verre, 50-3. 
Fontaine, S. (2010). 'Amphion et le dromadaire: Notes sur une marque sur verre de l'épave Tiboulen de Maïre', Bulletin de l'Association française pour l'Archéologie du Verre, $19-20$

Fontaine, S., and Foy, D. (2007). 'L'Épave Ouest-Embiez 1, Var: Le Commerce maritime du verre brut et manufacturé en Méditerranée occidentale', RANarb 40: 235-65.

Foy, D. (2003a). 'Le Verre antique en Tunisie: L'Apport des fouilles récentes tunisofrançaises', Journal of Glass Studies, 45: 59-89.

Foy, D. (2003b). Cour de verre: Production et diffusion du verre antique, catalogue d'exposition, pôle archéologique du Rhône. Gollion.

Foy, D. (2006). 'Les Marques sur les verres trouvés en France: Addenda', in CSMVA (2006b), 467-90

Foy, D. (2008). 'Les Officines de verriers de Marseille et d'Arles à la fin de l'Antiquité', in J.-E. Brochier, A Guilcher, and M. Pagni (eds), Archéologique de Provence et d'ailleurs: Mélanges offerts à Gaëtan Congès et Gérard Sauzade (Bulletin Archéologique de Provence, suppl. 5). Aix-en-Provence, 611-25.

Foy, D. (2011). 'Signatures et marques sur verres antiques trouvés en France: Second addendum', in CSMVA (2011), 83-138.

Foy, D. (2015). 'Les Marques sur les récipients en verre découverts en Gaule: Indices de production et de relations commerciales (milieu I ${ }^{\text {er }}$ s. $-V^{\mathrm{e}}$ s. apr. J.-C)', Gallia, 72/2: 351-401.

Foy, D., and Fontaine, S. (2008). 'Diversité et évolution des vitrages de l'Antiquité et du haut Moyen-Age: Un état de la question', Gallia, 65: 405-59.

Foy, D., and Nenna, M.-D. (2001). Tout feu tout sable: Mille ans de verre dans le Midi de la France. Catalogue d'exposition, musée d'Histoire, Marseilles and Aix-en-Provence.

Foy, D., and Nenna, M.-D. (2003). Échanges et commerce du verre dans le monde antique: Actes du colloque international de l'Association Française pour l'Archéologie $d u$ Verre, Aix-en-Provence et Marseille, juin 2001. Montagnac (Monographies Instrumentum 24).

Foy, D., and Nenna, M.-D. (2006a). 'Les Unguentaria', in CSMVA (2006a), 133-48 and pls 64-82.

Foy, D., and Nenna, M.-D. (2006b). 'Les Contenants tardifs', in CSMVA (2006a), 195-200 and pl. 122-3.

Foy, D., Picon, Vichy, M., and Thirion-Merle, V. (2003). 'Caractérisation des verres de la fin de l'Antiquité en Méditerranée occidentale: L'Émergence de nouveaux courants commerciaux', in Foy and Nenna (2003), 41-85.

Foy, D., Thirion-Merle, V., and Vichy, M. (2004). 'Contribution à l'étude des verres antiques décolorés à l'antimoine', Revue d'archéométrie, 28: 169-77.

Freestone, I (1994). 'Appendix: Chemical Analysis of "Raw" Glass Fragments', in H. R. Hurst (ed.), Excavations at Carthage, II, 1: The Circular Harbour, North Side. Oxford, 290

Freestone, I. (2006). 'Glass Production in Late Antiquity and the Early Islamic Period: A Geochimical Perspective', in M. Maggetti and B. Messiga (eds), Geomaterials in Cultural Heritage. London, 201-16.

Freestone, I., Gorin-Rosen, Y., and Hughes, M. (2000). 'Primary Glass from Israel and the Production of Glass in Late Antiquity and the Early Islamic Period', in Nenna (2000), 65-83.
Freestone, I., Wolf, S., and Thirlwall, M. (2005). 'The Production of HIMT Glass: Elemental and Isotopic Evidence', in Annales du $16^{e}$ congrès de l'Association internationale pour l'histoire du Verre (Londres 2003). Nottingham, 153-7.

Fremerdorf, F. (1961). Römisches geformtes Glas in Köln (Die Denkmäler des römischen Köln VI). Cologne.

Frova, A. (1971). 'Vetri romani con marchi', Journal of Glass Studies, 13: 38-44.

Gaitzsch, W., Follmann-Schulz, A.-B., Wedepohl, K. H., Hartmann, G., and Tegtmeier, U. (2000). 'Spätrömische Glashütten im Hambacher Forst - Produktionsort der ECVA - Fasskrüge', Bonner Jahrbücher, 200: 83-241.

Giacobelli, M. (1997). 'I vetri del relitto di Grado', in Atti del Convegno Nazionale di Archeologia Subacquea (Anzio 1996). Bari, 311-13.

Giacobelli, M. (2002). 'I vetri del relitto di Grado', Archeologia subacquea, 3: 255-73.

Glöckner, G. (2006). 'Signs, Inscriptions and other Designs on Roman Glass Vessels in Austria', in CSMVA (2006b), 187-208.

Goethert-Polaschek, K. (1977). Katalog der römischen Gläser des Rheinischen Landesmuseums Trier. Mainz.

Gorin-Rosen, Y. (2000). 'The Ancient Glass Industry in Israel: Summary of the Finds and New Discoveries', in Nenna (2000), 49-63.

Huisman, D. J., De Groot, T., Pols S., Van Os, B. J. H., and Degryse, P. (2009). 'Compositional Variation in Roman Colourless Glass Objects from the Bocholtz Burial (The Netherlands)', Archaeometry, 51/3: 413-39.

Ignatiadou, D., Dotsika, E., Kouras, A., and Maniatis, Y. (2005). 'Nitrum Chalestricum: The Natron of Macedonia', Annales du $16^{e}$ congrès de l'Association internationale pour l'histoire du Verre, (Londres 2003). Nottingham, 64-7.

Isings, C. (1957). Roman Glass from Dated Finds. Groningen-Djakarta.

Larese, A., and Zerbinati, E. (1998). Vetri antichi di raccolte concordiesi e polesane. Venice.

Ludi romani: Espectáculos en Hispania romana (2002): Catalogue d'exposition, Museo Nacional de Arte romano. Merida.

Mahéo, N. (1990). Les Collections archéologiques du musée de Picardie. Amiens.

Mandruzzato, L., and Marcante, A. (2007). Vetri antichi del Museo Archeologico Nazionale di Aquileia: Il vasellame da mensa. Trieste.

Massart, C., Fontaine-Hodiamont, C., and Saverwyns, S. (2004). 'Les Unguentaria du tumulus gallo-romain de Vorsen (com. de Montenaken, prov. de Limbourg): Restauration, marques et contenus', Bulletin de l'Institut Royal du Patrimoine, 30: $119-42$.

Maurin, L. (1978). Saintes Antique des origines à la fin du VI $T^{e}$ siècle après J.-C. Saintes. Menninger, M. (1996). Untersuchungen zu den Gläsern und Gipsabgüssen aus dem Fund von Begram (Afghanistan). Würzburg.

Mirti, P., Casoli, A., and Appolonia, L. (1993). 'Scientific Analysis of Roman Glass from Augusta Praetoria', Archaeometry, 35: 225-40.

Moirin, A. (2003). 'Contacts et échanges au I ${ }^{\text {er }}$ siècle: L'Exemple de la Gaule du Centre', in Foy and Nenna (2003), 211-25.

Moirin, A. (2006). 'Les Bouteilles rectangulaires', in CSMVA (2006a), 109-17.

Narbone, G. (1997). 'Vetri', in R. M. Boncasa Carra and R. Panvini (eds), La Sicilia centro-meridionale tra il II ed il VI sec. D.C.: Catalogo della mostra, CaltanissettaGela. Caltanissetta, 275-91. 
(1989). 'Vidi tunc adnumerari unius scyphi fracta membra:

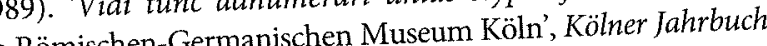
Kameoglas-Fragmente im Röm

für Vor- und Frühgeschichte, 22: 73-86. Nenna, M.-D. (1999). 'La Verrerie', in Bahrein la civilisa

Dilmoun à Tylos: Catalogue d'exposition. Paris, 181-91.

Nenna, M.-D. (2000). La Route du verre: Ateliers primaires et secondaires de venon, 1997) second millénaire av. J.-C. au Moyen Âge (actes de la table r

(Travaux de la Maison de l'Orient méditerranéen 33). Lyons. Nenna, M.-D. (2006). 'Marques de provenance inconnue

français', in CSMVA (2006a), 201-14 and pls 124-39. Nenna, M.-D. (2008a). 'Nouveaux acquis sur la production et le commerce $2007-$ antique entre Orient et Occident', Internationaler Kongress CRAFr Handwerk und Gesellschaft in den römisch

Archäologie und Kunstgeschichte, 65: 61-6.

Nenna, M.-D. (2008b). 'Un bol en verre peint du

nilotique', Journal of Glass Studies, 50: 15-29. 'Ateliers primaires et secondaires en

Nenna, M.-D., Picon, M., and Vichy, M. (2000). 'Ateliers prime

Égypte à l'époque gréco-romaine, in Nenna (200) Ne, V. (2005). 'Ateliers primaires

Nenna, M.-D., Picon, M., Vichy, M., and Thiron-Mnnales du $16^{e}$ congrès de l'AIHV du Wadi Natrun: Nouvelles

(Londres 2003). London, 56-63.

Nenna, M.-D., Vichy, M., and Picon, M. (1997). 'LAtelier de verie 81-7.

siècle et l'origine des verres romains', Revue d archeometrelva) in Spain', Journal of

Price, J. (1977). 'Roman Ung

Glass Studies, 19: 30-9.

Price, J. (1978). 'Trade in Glass', in J. du Plat Taylor and H. Cleere

Shipping and Trade: Britain and the Rhine Provinces. London, at Hertford Heath,

Price, J. (1996). 'A Ribbed Bowl from a Late Iron Age Burial ationale pour l'histoire Hertfordshire', Annales du $13^{e}$ congrès de lAss

du Verre (Pays-Bas 1995). Lochem, 47-54. Price, J. (2006). 'Mould-Blown and Impressed Designs and Names on Vessels in

Spain', in CSMVA (2006b), 283-320. Price, J. (2011). 'Mould-Blown and

Britain', in CSMVA (2011), 15-80.

Radić, I., and Jurišíc, M. (1993). 'Das antike Schiffswrack von Mljet (Krotien)', Germania, 71: 113-38. RIB: Collingwood, R. G., and Wright, R.P. (1991)

Instrumentum Domesticum, fasc. 2. Oxford. Rottloff, A. (2006). 'Bodenn

CSMVA (2006b), 145-92. Roussel-Ode, J. (2008). 'Une boutiqu

de n. è., RANarb 41: 285-301. Rütti, B. (2003). 'Les Verres peints du Haut Emp

diffusion', in Foy and Nenna (2003), 349-57. Sablerolles, Y. (2006). 'Marks on Glass Vess

(Belgium)', in CSMVA (2006b), 15-68
Simon-Hiernard, D. (2000). Verres d'époque romaine, collection des musées de Poitiers. Poitiers.

Spanu, P. G. (1997). 'Il relitto A di Cala Reale (L'Asinara 1): Note preliminari', in Atti del Convegno nazionale di archeologia subacquea (Anzio 1996). Bari, 109-19.

Stern, E. M. (1999). 'Roman Glassblowing in a Cultural Context', AJA 103: 441-84.

Sternini, M. (1993). 'I vetri', in W. V. Harris (ed.), The Inscribed Economy: Production and Distribution in the Roman Empire in the Light of Instrumentum Domesticum. Ann Arbor, 81-94.

Sternini, M., Agricoli, G., and Mazzei, C. (1997). 'Unguentari in vetro con bollo nelle collezioni del Museo Nazionale Romano', Annali della facoltà di Lettere e Filosofia dell'Università di Siena, 18: 55-100.

Taborelli, L. (1982). 'Vasi di vetro con bollo monetale: Note sulla produzione, la tassazione e il commercio degli unguenti aromataci nella prima età imperiale', Opus, 1: $315-40$

Taborelli, L. (1983). 'Nuovi esemplari di bolli già noti su contenitori vitrei dall'area centro-italica', Picus, 3: 23-69.

Taborelli, L. (1995). 'Contenitori di vetro con bollo: Un caso esemplare della loro problematica', Rivista Archeologica dell'Antica Provincia e Diocesi di Como, 177 71-87.

Taborelli, L. (1998). 'Riflessioni sul caso di un bollo vitreo con tria nomina forse ridotti a sigla', Athenaeum, 86: 286-91.

Tontini, S. (2006). 'Vetri e produzione vetraria a Classe (Ravenna) in età tardoantica e altomedievale', Bulletin de l'Association pour l'Antiquité tardive, 15: 45-54.

Tremmel, B. (2006). 'Glasgefässe und Glasperlen aus Haltern, Anreppen und Oberaden,' in Varia Castrensia, Haltern, Oberaden, Anreppen. Mainz am Rhein, 235-86. Triantafyllidis, P. (2006). 'Base Marks from Greece, Cyprus and Turkey', in CSMVA (2006b), 369-402.

Van Lith, S. M. E. (1996). 'Some Mould Blown Flavian Glass from Nijmegen', Annales $d u 13^{e}$ congres de l'Association Internationale pour l'histoire du Verre (Pays-Bas 1995). Lochem, 23-133.

Verità, M. (2001). 'Le Sable et le verre', in A. Ciarallo and E. Carolis (eds), Pompéi. Nature, Sciences et Techniques: Catalogue d'exposition, Paris, Palais de la découverte. Milan, 108-10.

Whitehouse, D. (1998). Excavations at Ed-Dur (Ummal-Qaiwain, United Arab Emirates), i. The Glass Vessels. Leuven.

Whitehouse, D. (2003). 'A Mold-Blown Bottle from the Workshop of Titianus Hyacinthus', Journal of Glass Studies, 45: 179-80. 